\title{
REINDUSTRIALIZATION AND STRUCTURAL CHANGE IN FUNCTION OF THE ECONOMIC DEVELOPMENT OF THE REPUBLIC OF SERBIA
}

\author{
Vladimir Micic* \\ Faculty of Economics, University of Kragujevac, Kragujevac, The Republic of Serbia
}

\begin{abstract}
This paper examines industrialization and structural change induced thereof, which are the main drivers and bearers of economic development. The author observes that the industry of the Republic of Serbia is devastated due to sudden and premature tertiarization as well as inadequate reforms. The current structures of both the economy and the industry do not have a sufficient capacity to ensure sustainable economic development; hence, the aim of the research presented in this paper is to emphasize the importance of reindustrialization and the implementation of structural changes in the Republic of Serbia. The paper starts from the premise that industry is the main driver and the bearer of economic growth and development. Therefore, it is necessary for the Republic of Serbia to turn to reindustrialization and implement structural changes in this sector given the fact that the levels of the development and competitiveness of the industry are correlated to the intensity of industrialization. The research findings indicate that developed industrial countries are characterized by more effective structural changes and more propulsive production that creates higher value-added products. This reflects not only at the level of the industrial development but also at the level of the competitiveness, volume and quality of exports.
\end{abstract}

Keywords: industrialization, structural change, the level of industry development and competitiveness, economic development

JEL Classification: L16, N1, O14, O25, O47

\section{INTRODUCTION}

The economic history of developed countries and the fast-growing BRICS economies (Brazil, Russia, India, China and South Africa) confirms that industry has a major role in the economic development of these countries by being its major driver and bearer.

\footnotetext{
* Correspondence to: V. Micic, Faculty of Economics, University of Kragujevac, D. Pucara 3, 34000 Kragujevac, The Republic of Serbia; e-mail: micicv@kg.ac.rs
}

Furthermore, thus far, the countries with a developed industrial sector have been less exposed to adverse effects of the global economic crisis. This crisis has also confirmed that there is no substantial economic progress without a developed industry where structural changes are implemented on a regular basis. The advantage of industrial development is that it requires constant changes in the industrial structure, which is particularly important for countries with a low production capacity, a low volume of exports and 
poor industrialization intensity. Structural change is a necessity in terms of the dynamic development of science, knowledge and technological innovation, while the results depend on the rate and efficiency of its implementation.

The industry of the Republic of Serbia (RS) has been locked in a deep crisis for a long time; the global economic crisis has intensified and brought to light all the weaknesses of the economic and industrial development. The deindustrialization of the economy and the devastation of the industry inevitably brought about by the transition have made the economic growth completely unsustainable. The past and present experiences and practices of developed countries, the fast-growing BRICS economies and advanced transition countries show that the stable economic development of RS can only be achieved through the country's industrialization and reindustrialization - industrialization is needed because certain activities have utterly been devastated and require that a start should be made from scratch, while reindustrialization is required in order to improve the intensity of production and increase the level of the competitiveness of the industry.

Therefore, the industrialization of RS and a structural change that should be in function of an efficient industrial development as well as the sustainable development of the economy as a whole are the subject matter of this study. Reindustrialization is a way out of the economic crisis and a path to the successful implementation of a number of socio-economic goals.

Based on the relevant information on the degree of the devastation of the Serbian industry and the low level of the GDP per capita, the objective of this paper is to underline the importance of the effective implementation of reindustrialization and structural changes for a sustainable economic and social development. The importance of reindustrialization is further supported by contrasting the results of the comparisons made between RS and the countries undergoing industrialization (Bulgaria, Croatia) as well as a group of industrialized countries (the Czech Republic, Slovakia, Hungary and Slovenia) in terms of economic and industrial development and implemented structural reforms. These are all small countries, which, with the exception of Bulgaria, are at a significantly higher level of economic development compared to RS, as measured by the GDP per capita.

In accordance with the set objective and the purpose of the research, the paper starts from the following hypotheses:

H1: Given the fact that the industry is the driver and the bearer of the economic growth and development in RS, it is necessary that reindustrialization be carried out and structural changes in the industry be implemented.

H2: The level of the development and competitiveness of the industry is in a direct correlation with the intensity of industrialization.

In order to confirm the aforestated hypotheses, the following indicators related to development and structural changes have been used: the industrial production growth rates and indices, the share the industry has in the GDP, the GVA (Gross Value Added) and employment, the GVA of the processing industry per employee and the volume and structure of exports in terms of the technological intensity and the Standard International Trade Classification, Revision 4 (SITC, Rev. 4). A comparative method has been employed to analyze and compare the industrial performance and structural changes in Bulgaria, the Czech Republic, Croatia, Hungary, Slovakia, Slovenia and RS. The application of this methodology has been considered to be the most suitable for identifying the data and information that can contribute to initiating reindustrialization. The methodology of the United Nations Industrial Development Organization (the UNIDO methodology) is relevant for the assessment of the degree of industrialization and industrial competitiveness. A correlation analysis has been used to determine the nature and the type of the correlation among the achieved level of development, competitiveness and the intensity of industrialization.

The paper is organized into eight sections. Following the introduction, the second section provides an overview of the literature on industrialization and structural changes. The third section analyzes the pace of the industrial development and the economic crisis in RS in the period of transition. The fourth section discusses the experience of the premature 
and rapid deindustrialization of the economy and the devastation of the industry in RS. In the fifth section, the assessment of the achieved level of the industrial development of RS and the observed countries is given, whereas in the sixth section, the research findings concerning the industries of the mentioned countries are presented. The seventh section analyzes the main production and export activities which call for structural changes in the Serban industry. The concluding remarks are presented in the eighth section of the paper.

\section{LITERATURE REVIEW}

The industrialization process, which has been lasting for some 250 years already (i.e. since the beginning of the Industrial Revolution), is usually seen as an economic development strategy. It has different priorities and modes of implementation in different countries, depending on the level of a country's development and the time when this process was introduced (Pack \& Westphal, 1986). Industrialization is synonymous with economic development, wealth, technological leadership and innovation, economic and political power and international dominance (Szirmai, Naude \& Alcorta, 2013). Industrial development is considered to be the key driver of the structural change and transformation of an economy, which is of particular importance for developing countries. Along with the changing structure of an economy, and changes in the share of an industry in the GDP and employment, the structure of an industry also changes, especially the manufacturing one. The intensity of changes is inversely related to a country's level of development - the higher the intensity of change, the lower the level of development.

Structural change refers to changes in the composition of an aggregate, which affects the relative significance of economic sectors or their parts, and is strongly interrelated with economic development (Syrquin, 2007). It involves a shift from traditional activities to newer, highly productive ones (Rodrik, 2008). Furthermore, industries have higher levels and dynamics of productivity than other sectors do (Szirmai, 2012). Industry induces productivity growth in other sectors, which is essential for an increase in competitiveness.

Structural change introduced in an industry leads to changes in relationships and a transformation in the composition of the production factors, production output, employment, supply, demand, investment and trade (Doyle, 1997). The flexible manufacturing structure established in this way is an important element of productivity growth, which allows an efficient redistribution and reallocation of resources (Fagerberg, 2000; Jakopin, 2012).

The countries that failed to implement structural change in the industry are lagging behind and have hardly moved away from traditional production (Lin, 2012). In developing countries, the structural transformation from the traditional manufacturing industries to the technologically advanced ones characterized by higher productivity rates, improved competitiveness and higher value-added products - is an essential condition for an increase in the intensity of industrialization. This is the basis for the creation of new jobs and the achievement of a sustainable economic development. The critical drivers of intensive industrial development and structural change in an industry are: knowledge, skills, innovation, technology, demand, resource efficiency, investment, the company size, value chain activities, agglomeration effects and the industrial policy (UNIDO, 2013a).

The industrial policy is an important factor in the process of industrialization and structural change. The fact is that industrialized economies have provided different kinds of development support to their industries (Lin \& Chang, 2009). In addition to correcting market failures, the main task of the industrial policy is to initiate and accelerate structural change (Syrquin, 2007). The fast-growing BRICS economies owe their success to the industrial policy that affected the successful development of the industrial sector, technological capabilities and competitiveness (Naude, Szirmai \& Lavopa, 2013). It is clear that the reason for considering the role of the state in development, as well as the active and sophisticated industrial policy (Rodrik, 2007), is prompted by the development of technologically competitive industries. In this case, the industrial policy is aimed at improving the business environment and the continuous transformation of 
the industrial structure towards the activities that will ensure sustainable economic development and social well-being (Rodrik, 2009; Wade, 2012; Aiginger, 2014).

Today, many countries are faced with two major challenges - deindustrialization and reindustrialization (Kucera \& Milberg, 2003; Palma, 2008; Tregenna, 2009). Industrialization remains an important goal for the majority of developing countries, particularly those that are undergoing economic transition. The global economic crisis has underlined reindustrialization as one of the critical present and future challenges related to the economic development of the mentioned countries. Reindustrialization also has a major role in developed countries, primarily due to competition among rapidly growing economies.

However, many advanced economies with a higher GDP per capita are actually deindustrialized due to a faster productivity growth in the manufacturing sector than in services, increased demand for services rather than manufactured goods and the expansion of trade linkages between developed and developing countries (Kollmeyer, 2009). Here, deindustrialization shows the maturity of the industrial sector and the economic structure, while the predominant share of high-tech industries leads to losing the identity of the classical industrial structure (Tregenna, 2011).

In this respect, deindustrialization can be both the positive and the negative process (Rowthorn \& Coutts, 2004). In the positive context, productivity records a faster growth than that of the production output; therefore, the number of jobs in the manufacturing sector decreases in both absolute and relative terms. However, unemployment is not the consequence. Redundant workers are reallocated to the service industry, where new jobs are being created, which enables economic growth. Otherwise, deindustrialization leads to major problems in economic development, as is the case in the countries of Central and Eastern Europe (Mickiewicz \& Zalewska, 2005). This type of deindustrialization occurs in a much earlier phase of industrialization and at the lower level of the GDP per capita than that in developed countries.

In developed countries, deindustrialization is accompanied by efficient reindustrialization. Surely, reindustrialization is one of the challenges related to premature deindustrialization in developing countries. However, there are many other challenges (Tregenna, 2011).

In order to restore an increased share of the industrial sector in the GDP and employment, more efforts are needed than it would have been the case at the beginning of or during industrialization. One of the reasons for such a situation is also change in the development paradigm, where a successful development no longer exclusively depends on the availability of natural resources, cheap labor and capital. The efficient industrial sector also depends on the factors considered to be the basis of highlysophisticated reindustrialization, the strengthened role of propulsive industries and the creation of new knowledge- and technology-based products as well as the emergence of the service industries. Such a shift from deindustrialization to reindustrialization points to the significance and importance of the industrial policy, which can be employed to enable continuous structural change.

\section{THE PACE OF INDUSTRIAL DEVELOPMENT}

In the aftermath of the WW II, the level of the development of the Serbian economy, as well as the economies of the other federal republics of the SFRY, spurred the economic development strategy based on general industrialization, i.e. it focused on the model of rapid industrialization as the essence of the industrial strategy. The aim was to achieve a rapid and dynamic economic development, where industrialization was a means for the realization of broader socio-economic objectives. The bearer of industrialization was the state, which rather employed the economic policy than an adequate industrial one in order to steer the very process of industrial development.

Although the pace of industrialization varied in the different periods of the industrial development, the overall effects of the industrial development achieved in RS (measured by the volume of production) were very significant at the end of the 1980s (Figure 1). With the GDP per capita of about 1,450 USD (at current 


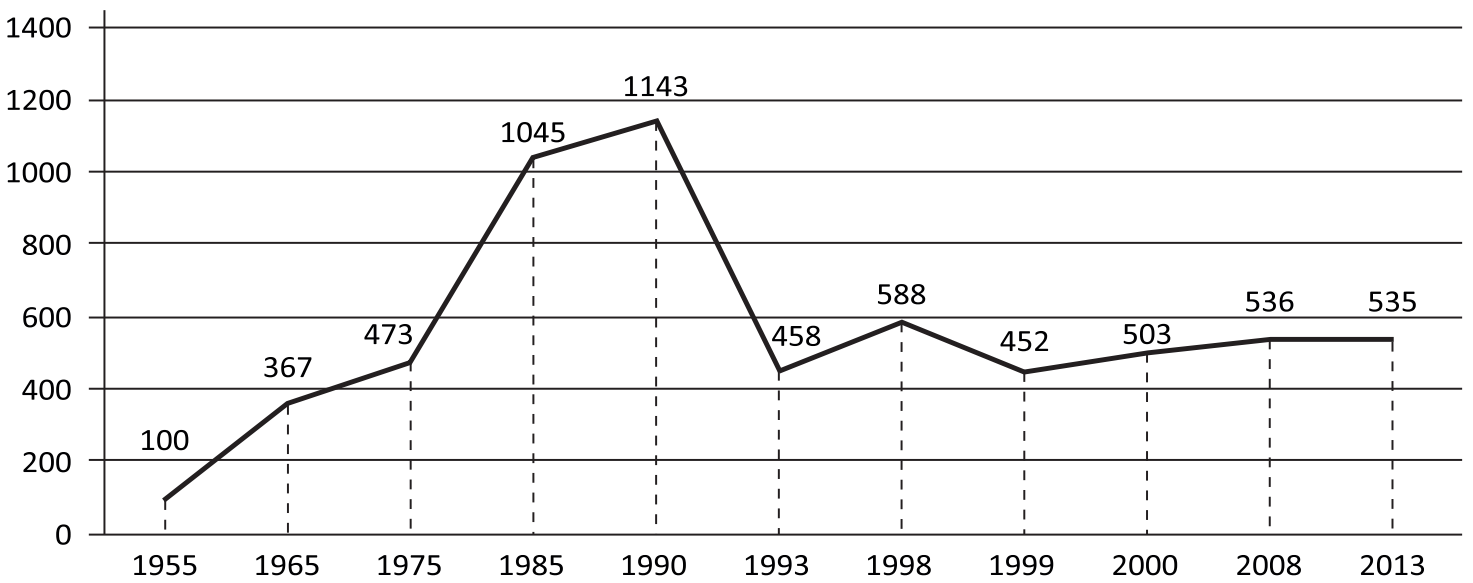

Figure 1 The index of the physical volume of industrial production in 1955-2013

Source: Author, based on: The Statistical Office of the Republic of Serbia (SOR), 2015.

prices in 2000) at the time of the breakup of the former Yugoslavia, the Serbian industry reached the central and most delicate phase of development balancing. The rapid pace of the industrial growth made the industry contribute most significantly to the economic growth, accounting for about $44 \%$ in the creation of the total product.

The initiated transition process of the economic system in the early 1990s also marked the beginning of the industrial development crisis. The slow pace of transition during the 1990s as well as its intensification after 2000 led to a sharp decline in industrial production. The decline was the result of the slow and inefficient transformation of the old economic system and the delayed and inadequate establishment of the new one as well as of other numerous internal and external non-economic factors. Industrial production recorded an average decrease of $7.5 \%$ (5.5\% of the GDP) in the last decade of the twentieth century (Table 1). In contrast to RS, the other countries that are the subject matter of the analysis, showed a slight decline in production. The structural reforms implemented in the industrial sector, particularly in the countries of Central Europe, became an integral part of the transition process of these economies. Changes in the production structure are the result of the growth of the domestic and foreign investment and the reallocation of production facilities from developed countries as well as access to the EU market. As early as in the initial stage of the transition, it became clear that the implementation of structural changes in the manufacturing sector was vital in order to ensure a successful recovery and industrial growth in these countries.

Table 1 Average industrial growth rates, 1991-2000

\begin{tabular}{l|ccc}
\hline Country & $1991-2000$ & $2001-2008$ & $2009-2013$ \\
\hline Bulgaria & -5.7 & 7.0 & -2.1 \\
Czech Republic & -1.7 & 5.5 & 0.1 \\
Croatia & 5.9 & 4.0 & -3.8 \\
Hungary & 3.8 & 5.7 & -0.3 \\
Slovakia & -0.8 & 9.5 & 2.2 \\
Slovenia & -1.5 & 3.8 & -2.1 \\
The Republic of Serbia & -7.5 & 2.0 & -1.1 \\
\hline
\end{tabular}

Source: Author, based on: European Bank for Reconstruction and Development (EBRD), 2015 
In the first decade of the 21st century, RS showed an extremely low pace of industrial growth, which concerning the favorable market trends prior to 2008 - resulted in a much lower average annual growth rate $(2 \%)$ compared to the other observed countries. The cause for such a situation can be found in the reforms brought about by the transition process and the numerous structural limitations that have led to the rapid tertiarization of the economy. The additional deceleration of production has also resulted from the contraction of the economic activity and a decline in export demand from 2008 onwards. The rate of production growth was negative and far below the achieved one prior to the crisis. The slowdown of the economic, structural and institutional changes has affected the pace of the economic recovery and production growth.

According to the official statistical data, the level of industrial production in 2013 amounted to only about $50 \%$ of the level achieved in 1990. To be more precise, the level of industrial production in 2013 did not exceed the physical volume of production in 1998 (SOR, 2015). The comparative analysis of the growth of the physical volume of industrial production showed that in 2013 this volume increased in Slovakia (by 86\%), the Czech Republic (by $45 \%$ ) and Hungary (by $45 \%$ ) compared to 2000. The level of the physical volume of industrial production in RS increased by only $10 \%$ (Table 2 ) in the same period.

Table 2 The industrial production index, 2000 $=100$

\begin{tabular}{l|cc}
\hline Countries & 2001-2008 & 2001-2013 \\
\hline Bulgaria & 155 & 145 \\
Czech Republic & 144 & 145 \\
Croatia & 132 & 113 \\
Hungary & 145 & 145 \\
Slovakia & 175 & 186 \\
Slovenia & 130 & 119 \\
The Republic of Serbia & 115 & 110 \\
\hline
\end{tabular}

Source: Eurostat, 2015
The rate of industrial growth in RS confirms two facts. The first fact is that the Serbian industry has been in severe crisis for a long time and that this crisis is of a structural rather than cyclical nature, for which reason an implementation of significant structural changes is required. The second fact is that there were no significant structural changes in terms of achieving a more modern and propulsive industrial structure because such changes can only occur in a period that follows a more dynamic industrial growth.

\section{THE DEINDUSTRIALIZATION OF THE ECONOMY AND THE DEVASTATION OF THE INDUSTRY}

The growth in the share of the service sector joined with the reduction in the share of the real sector in production and employment represent the common features of the transition process. As such, they have influenced the onset of the deindustrialization of the Serbian economy and the economies of the observed countries. Unlike RS, more advanced transition countries started the process of reindustrialization concurrently with deindustrialization, which resulted in a more/less successful increase in industrial production early in 2008. This was also the reason why the intensity of structural changes, concerning manufacturing and services, was somewhat more moderate than the one in RS.

The sharp average decline in industrial production from 1990 to 2000 (-7.5\%) as well as its development at an average rate that was 3.5 times lower than the GDP growth (about 3\%) after 2001, led to a drastic decrease in the share of the industry in the GDP. In 2010, the share of the industry in the GDP was $21.4 \%$, while in 2001, it was 30\% and in 1991, even about 44\% (Table 3). The other observed Central European countries show a significantly smaller and slower decline in the share of the industry in the GDP in the same period.

The analysis of the gross value added (GVA) based on the production sector shows a decline in the share of the manufacturing industry, whereas at the same time, the share of the service sector increases. 
Table 3 The share of the industry in the GDP

\begin{tabular}{l|cccccc}
\hline Country & 1991 & 1996 & 2001 & 2006 & 2010 & $\begin{array}{c}\text { Change } \\
1991-2010\end{array}$ \\
\hline Bulgaria & 39.8 & 29.0 & 25.2 & 26.1 & 22.6 & -17.2 \\
Czech Republic & 37.9 & 33.8 & 37.5 & 41.9 & 37.7 & -0.2 \\
Croatia & 21.5 & 20.2 & 19.0 & 17.7 & 19.5 & -2.0 \\
Hungary & 21.0 & 23.5 & 26.4 & 26.1 & 26.8 & 5.8 \\
Slovakia & 35.2 & 29.5 & 25.8 & 28.3 & 25.3 & -9.9 \\
Slovenia & 36.0 & 25.4 & 25.9 & 23.8 & 24.2 & -11.8 \\
The Republic of Serbia & 44.4 & 26.0 & 30.0 & 21.8 & 21.4 & -23.0 \\
\hline
\end{tabular}

Source: Author, based on: EBRD, 2015; United Nations Economic Commission for Europe (UNECE), 2015

In 2013, the largest share of the manufacturing industry in the GVA was achieved in the Czech Republic (28.7\%), while the largest decrease (since 2001) was recorded in Slovakia $(-3.2 \%)$ and RS (-2.6\%). Unlike RS, Bulgaria showed an increase in the share of the manufacturing industry in the GVA (Tables 4 and 5). It is evident that the share of the service sector in the GVA in RS is similar to that of the Czech Republic and Slovakia; however, the intensity of the growth of this sector is much greater in RS. Such a trend is due to the fact that the average growth rate of the industry's GVA is among the lowest ones $(1.7 \%)$, while that of the service sector is among the highest ones (3.3\%), concerning the surveyed countries. In contrast to the observed countries, the economy of RS recorded a decline in the share of agriculture and construction, i.e. the entire real sector, in the GVA.

Furthermore, in RS, the number of workers employed in the industry was reduced in both absolute and relative terms. The total number of employees was decreased from 674,000 persons in 2001 to 337,000 in 2013. At the same time, the number of employees in the manufacturing industry decreased by 317,000 persons (SOR, 2015).

Sectoral changes in the staffing structure are characterized by an increasing number of employees in the service sector, which is also the case in the other observed countries (Table 6). However, the service sector has not created enough jobs to compensate for the huge job loss in the manufacturing sector; therefore, a certain number of industrial workers were reallocated to the agricultural sector. The fact that the unemployment rate was about 23\% in 2013 (SOR, 2015), while the involvement of employees in the manufacturing industry was lower than that in agriculture, best reflects the level of the economic development, the participation of the manufacturing industry in the development and its current state.

Compared to the other countries, the share of employees in the industrial sector is lower, while the

Table 4 The share in the GVA, by the sector

\begin{tabular}{l|cccccccc}
\hline & $\begin{array}{r}\text { Sector } \\
\text { production } \\
\text { activity }\end{array}$ & \multicolumn{2}{|c}{ Agriculture } & \multicolumn{2}{c}{ Industry } & \multicolumn{2}{c}{ Construction } & \multicolumn{2}{c}{ Services } \\
\cline { 3 - 9 } Country & 2001 & 2013 & 2001 & 2013 & 2001 & 2013 & 2001 & 2013 \\
\hline Bulgaria & 10.5 & 4.7 & 18.9 & 19.9 & 4.5 & 4.1 & 66.1 & 71.3 \\
Czech Republic & 3.0 & 2.3 & 28.7 & 27.9 & 5.6 & 5.0 & 62.7 & 64.8 \\
Croatia & 5.3 & 3.6 & 19.4 & 17.9 & 4.6 & 4.5 & 70.7 & 74.0 \\
Hungary & 4.9 & 3.7 & 22.5 & 22.1 & 4.7 & 3.3 & 67.9 & 70.9 \\
Slovakia & 4.5 & 3.7 & 25.8 & 22.6 & 5.7 & 7.8 & 64.0 & 65.9 \\
Slovenia & 2.6 & 1.8 & 25.2 & 23.1 & 5.4 & 4.6 & 66.5 & 70.5 \\
The Republic of Serbia & 17.8 & 7.9 & 25.0 & 22.4 & 4.3 & 4.3 & 52.9 & 65.4 \\
\hline
\end{tabular}

Source: Author, based on: The Eurostat data, 2015; UNECE, 2015; SOR, 2015 
Table 5 GVA - The average growth rate and change in the share (+/-), 2001-2013, \%

\begin{tabular}{l|cccccccc}
\hline & $\begin{array}{r}\text { Sector } \\
\text { production } \\
\text { activity }\end{array}$ & \multicolumn{2}{|c}{ Agriculture } & \multicolumn{2}{c}{ Industry } & \multicolumn{2}{c}{ Construction } & \multicolumn{2}{c}{ Services } \\
\cline { 2 - 9 } Country & Avg. & $(+/)$ & Avg. & $(+/-)$ & Avg. & $(+/-)$ & Avg. & $(+/-)$ \\
\hline Bulgaria & -1.4 & -5.8 & 3.8 & +1.0 & 3.7 & -0.4 & 4.0 & +5.2 \\
Czech Republic & -0.3 & -0.7 & 3.8 & -0.8 & 0.7 & -0.6 & 2.1 & +2.1 \\
Croatia & -0.8 & -1.7 & 0.5 & -1.5 & 2.3 & -0.1 & 2.3 & +3.3 \\
Hungary & 3.5 & -1.2 & 1.4 & -0.4 & -0.1 & -1.4 & 2.0 & +3.0 \\
Slovakia & 6.8 & -0.8 & 6.1 & -3.2 & 4.6 & +2.1 & 3.4 & +1.9 \\
Slovenia & 0.3 & -0.8 & 1.7 & -2.1 & -0.7 & -0.8 & 2.3 & +0.8 \\
The Republic of Serbia & 1.9 & -9.9 & 1.7 & -2.6 & 4.5 & 0.0 & 3.3 & +12.5 \\
\hline
\end{tabular}

Source: Author, based on: The Eurostat data, 2015; UNECE, 2015; SOR, 2015

share of the people involved in the agricultural sector is high. According to the given data, Bulgaria is in a situation similar to the situation in RS. However, in the Czech Republic and Slovakia, the share of the people employed in agriculture is 6.5 times smaller than that in RS, in Hungary 3 times, in Slovenia 2.5 times and in Croatia 2 times. The countries in the higher stages and in a more successful process of industrialization have a share of the people employed in agriculture significantly below $10 \%$.

The rapid and intensive decline in the share of the industry in the GDP, the GVA and employment, together with the sharp increase in the share of the service sector and a large number of people employed in agriculture, cannot be attributed to deindustrialization characteristic for developed countries. In addition, in this case, deindustrialization is by no means the result of the maturity of the industrial sector. In the case of RS, the premature deindustrialization can rather be observed as a negative process that led to the devastation of the industry.

The conclusion that the deindustrialization in RS is premature and not a common one is supported by the fact that, in developed countries, the maximum

Table 6 The share and change of employees per sector, 2001-2013, \%

\begin{tabular}{|c|c|c|c|c|c|c|c|c|c|c|c|c|}
\hline \multirow[b]{2}{*}{ Country } & \multicolumn{3}{|c|}{ Agriculture } & \multicolumn{3}{|c|}{ Industry } & \multicolumn{3}{|c|}{ Construction } & \multicolumn{3}{|c|}{ Services } \\
\hline & 2001 & 2013 & $(+/-)$ & 2001 & 2013 & $(+/-)$ & 2001 & 2013 & $(+/-)$ & 2001 & 2013 & $(+/-)$ \\
\hline Bulgaria & 23.9 & 19.2 & -4.7 & 23.2 & 19.9 & -3.3 & 4.1 & 5.2 & +1.1 & 48.8 & 55.7 & +6.9 \\
\hline Czech Republic & 4.6 & $3 \cdot 3$ & -1.3 & 30.6 & 28.4 & -2.2 & 8.3 & 8.4 & +0.1 & 56.5 & 59.9 & +3.4 \\
\hline Croatia & 16.2 & 10.7 & -5.5 & 23.6 & 20.4 & -3.2 & 6.4 & 7.1 & +0.7 & 53.8 & 61.8 & +8.0 \\
\hline Hungary & 11.5 & 7.1 & $-4 \cdot 4$ & 26.3 & 20.8 & -5.5 & 6.0 & 6.4 & +0.4 & 56.2 & 65.7 & +9.5 \\
\hline Slovakia & 5.9 & 3.4 & -2.5 & 28.1 & 23.6 & -4.5 & 5.9 & 7.6 & +1.7 & 60.1 & 65.4 & +5.3 \\
\hline Slovenia & 11.1 & 8.4 & -2.7 & 29.3 & 22.7 & -6.6 & 7.3 & 6.8 & -0.5 & 52.3 & 62.1 & +9.8 \\
\hline The Republic of Serbia & 19.5 & 21.3 & +1.8 & 34.0 & 19.6 & -14.4 & 5.4 & 4.8 & -0.6 & 41.1 & 54.3 & +13.2 \\
\hline
\end{tabular}

Note: The data comparison was done according to the activity classification from 2010; agriculture includes Sector $\mathrm{A}$ 
participation of the industry in the GDP is achieved at the level of the GDP per capita between 3,000 and 3,500 USD. In RS, the deindustrialization process began in 1990 at the GDP per capita of 1,450 USD (at the current prices in 2000). That this process was not the result of a mature industry and an advanced economy is evidenced by the achieved level of the GDP per capita of only 1,300 USD in 2011. The accent on extensive industrialization in the period before the transition was certainly one of the reasons for such a situation. Since the beginning of the transition - without neglecting the importance and impact of the sociopolitical environment and factors - the devastation of the industry has been the result of the inefficient and ill-conceived concept of transitional reforms and the inadequate economic development strategy implemented in the critical stage and at the critical level of industrial development. This produced deep systemic and structural imbalances in the economy, whose side-effect is the tertiarization of the economy, with the very slow pace of development shown by the GDP per capita growth rate as their major consequence.

\section{The achieved level of industrialization}

Structural changes in the industry, particularly the manufacturing one, affect the achieved level (degree) of the development of the entire industry. The latter directly affects the level of the productivity of the industry and its competitiveness, i.e. the volume, the structure and the quality of exports.

The level of the industrialization of RS and the observed countries can be expressed and comparatively analyzed by UNIDO's quantitative indicators, which present the results and the trends related to the manufacturing industry. According to UNIDO's classification and the level of the industrial development of RS in 2013, the country was classified into the group of the economies undergoing the process of industrialization and in the industrial sub-group of developing industrial economies (UNIDO, 2013b). Concerning the other countries that are the subject matter of the research, only Bulgaria and Croatia are classified into this group. The Czech Republic, Slovakia, Hungary and Slovenia are classified into the group of industrialized economies.
The production capacity and exports of the manufacturing industry are low (Table 7). The manufacturing value added per capita (MVApc) and manufactured exports per capita (MXpc) are particularly very low. Compared to the Czech Republic, which has the highest MVApc and MXpc of all the countries observed, RS has the 12 times lower production capacity of the manufacturing industry and 15.5 times lower exports. Bulgaria, which, according to the level of the development of the industry, belongs to the same group as RS, has a production capacity over 2 times higher than that of RS's and exports which are almost 3 times as high.

Table 7 The manufacturing industry production capacity and exports

\begin{tabular}{lcccccc}
\hline & \multicolumn{2}{c}{ MVApc } & Index & \multicolumn{2}{c}{ MXpc } & Index \\
Country & 2006 & 2013 & $2013 / 06$ & 2006 & 2013 & $2013 / 06$ \\
\hline Bulgaria & 560 & 712 & 127 & 1,471 & 2,639 & 179 \\
Czech Republic & 3,287 & 3,872 & 118 & 8,572 & 14,364 & 168 \\
Croatia & 1,555 & 1,363 & 88 & 2,063 & 2,738 & 133 \\
Hungary & 2,230 & 2,403 & 108 & 6,526 & 9,812 & 150 \\
Slovakia & 2,194 & 3,505 & 160 & 7,009 & 13,389 & 191 \\
Slovenia & 3,852 & 3,644 & 95 & 9,444 & 12,784 & 135 \\
$\begin{array}{l}\text { The Republic } \\
\text { of Serbia }\end{array}$ & 391 & 320 & 82 & 533 & 931 & 175 \\
\hline
\end{tabular}

Source: UNIDO, 2013b; UNIDO, 2015

The fact that it will take RS 9.5 years to catch up with the Bulgarian MVApc - assuming that RS's MVApc grows at an average rate of $10 \%$ per annum - while at the same time Bulgaria's MVApc decreases, best speaks of the achieved level of the industrial development in RS measured by the production capacity. Although MXpc has increased by $75 \%$ since 2006, which is about 9.5\% a year on average, the above-mentioned estimate concerning the level of MVApc, supports the even more pessimistic assessment regarding exports.

The intensity of industrialization and the export quality, i.e. the level of the industrial technological 
development of RS, is at a low level. In addition to its very low level, the intensity of industrialization is also declining (Table 8). The contribution of the manufacturing sector to the manufacturing value added share in the total GDP (MVAsh) of the economy is a modest one. There were no significant qualitative changes in terms of the industrial structure, the increased technological complexity, knowledge transfer and technological modernization; therefore, there was no increase in the medium- and hightech manufacturing value added share in the total manufacturing value added (MHVAsh), which is reflected in the volume and quality of exports.

Table 8 Industrialization intensity

\begin{tabular}{|c|c|c|c|c|c|c|}
\hline \multirow[b]{2}{*}{ Country } & \multicolumn{2}{|c|}{ MVAsh, \% } & \multirow{2}{*}{$\begin{array}{l}\text { Change } \\
2006-13\end{array}$} & \multicolumn{2}{|c|}{ MHVAsh, \% } & \multirow{2}{*}{$\begin{array}{l}\text { Change } \\
\text { 2006-13 }\end{array}$} \\
\hline & 2006 & 2013 & & 2006 & 2013 & \\
\hline Bulgaria & 14.0 & 16.0 & +2.0 & 24.2 & 25.6 & +1.4 \\
\hline $\begin{array}{l}\text { Czech } \\
\text { Republic }\end{array}$ & 24.2 & 28.5 & +4.3 & 44.4 & 44.6 & +0.2 \\
\hline Croatia & 14.6 & 14.6 & 0.0 & 31.7 & 31.7 & 0.0 \\
\hline Hungary & 19.6 & 22.2 & +2.6 & 53.4 & 53.4 & 0.0 \\
\hline Slovakia & 20.9 & 31.5 & +10.6 & 39.8 & 43.2 & +3.4 \\
\hline Slovenia & 20.5 & 18.9 & -1.6 & 42.6 & 45.2 & +2.6 \\
\hline $\begin{array}{l}\text { The Republic } \\
\text { of Serbia }\end{array}$ & 17.7 & 12.0 & -5.7 & 20.7 & 20.0 & -0.7 \\
\hline
\end{tabular}

Source: Author, based on: UNIDO, 2013b; UNIDO, 2015

Furthermore, in terms of the export quality, RS significantly lags behind (Table 9). The changes in the structure of the manufacturing industry result in the very low medium- and high-tech manufactured exports share in the total manufactured exports (MHXsh). The manufactured exports share in the total exports (MXsh) was reduced by $1.6 \%$, although regarding the structure of the exports, the share of medium and high technology-intensive products has increased by $7.7 \%$. The global economic crisis reduced the export of natural resource- and labor-intensive products, which affected the quantity and quality of exports from RS.
Table 9 The export quality

\begin{tabular}{lcccccc}
\hline & \multicolumn{2}{c}{ MXsh, \% } & Change & \multicolumn{2}{c}{ MHXsh, \% } & Change \\
Country & 2006 & 2013 & $2006-13$ & 2006 & 2013 & $2006-13$ \\
\hline Bulgaria & 74.9 & 78.0 & +3.1 & 27.7 & 35.9 & +8.2 \\
Czech Republic & 92.4 & 93.2 & +0.8 & 66.1 & 67.9 & +1.8 \\
Croatia & 88.7 & 87.9 & -0.8 & 44.6 & 47.8 & +3.2 \\
Hungary & 88.2 & 90.1 & +1.9 & 78.0 & 75.6 & -2.4 \\
Slovakia & 91.2 & 94.4 & +3.2 & 60.8 & 64.8 & +4.0 \\
Slovenia & 90.3 & 89.8 & -0.5 & 60.3 & 61.3 & +1.0 \\
The Republic of & 81.5 & 79.9 & -1.6 & 26.0 & 33.7 & +7.7 \\
Serbia & & & & & & \\
\hline
\end{tabular}

Source: Author, based on: UNIDO, 2013b; UNIDO, 2015

RS's impact on the world manufacturing value added (ImWMVA) and the world manufactures trade (ImWMT) is very low. In comparison with RS, the more industrialized Czech Republic, Hungary and Slovakia, show much higher impacts of their manufacturing sectors on the world manufacturing value added and the world manufactures trade (Figure 2).

It can be noted that the basic indicators of the level of the manufacturing industry development in RS are at a low level (Tables 7, 8 and 9). More precisely, of the surveyed countries, RS has the lowest level of industrial development. The decreasing trend observed in the majority of the indicators in 2013 compared to 2006, indicates the consistency of the negative trends in the industry as well as the deindustrialization of the economy.

\section{The achieved level of the industry's competitiveness}

The competitiveness of the manufacturing industry, which produces the largest part of tradable goods, is one of the key factors for a sustainable economic development. Labor productivity in the manufacturing industry is the key indicator of competitiveness. It is also an important indicator of the structural changes in the surveyed countries, i.e. the capacity of their industries to grow, develop and export. Labor productivity can be expressed as the ratio of the value added per employee (Table 10). 


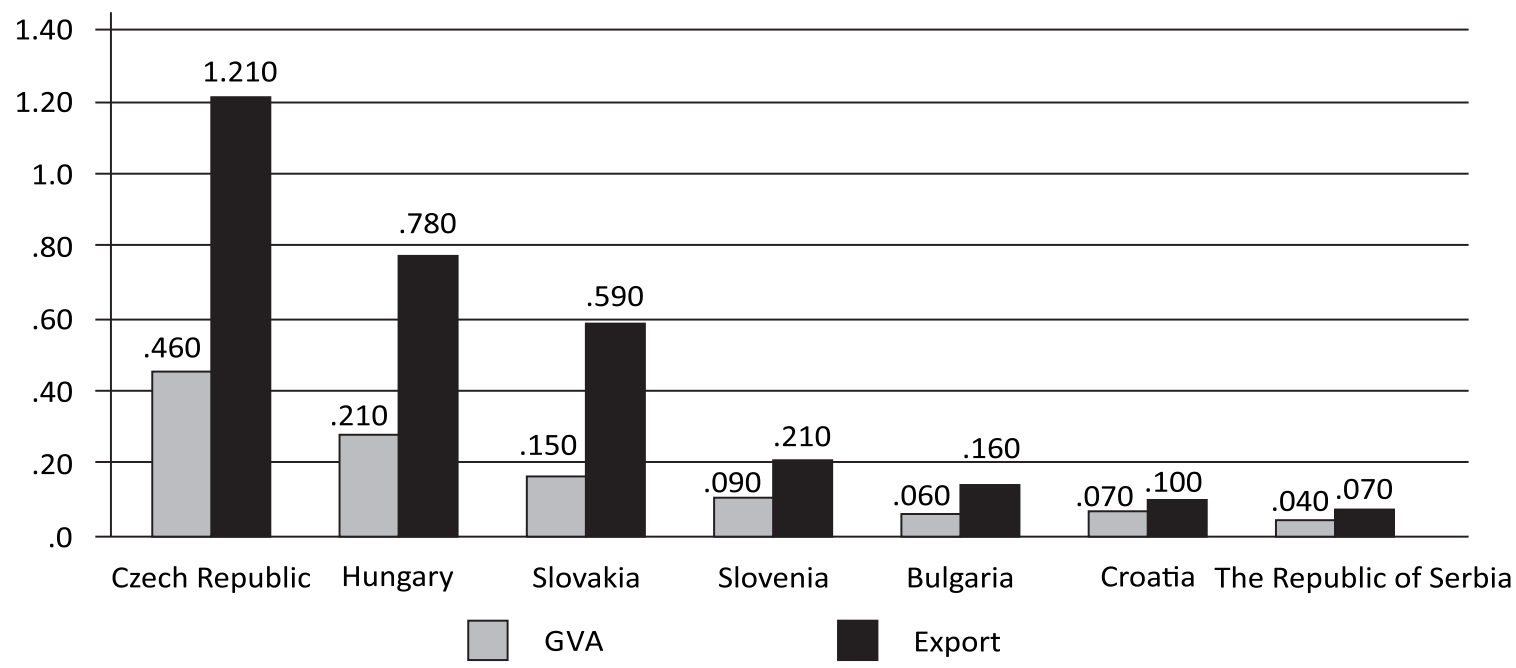

Figure 2 The share in the world manufacturing value added and exports in 2013

Source: Author, based on: UNIDO, 2013b; UNIDO, 201

In the period from 2006 to 2013, the Serbian manufacturing industry recorded the highest growth in labor productivity (measured by the GVA per employee) among the surveyed countries. Its average growth of $13.3 \%$ per year was the result of a large reduction in the number of employees in the manufacturing sector (5\%) and the significantly lower growth in the GVA (3.2\%). Given the level of unemployment, such a productivity growth is unsustainable. Here, productivity growth is not the result of investments and the technological modernization of the production activities that improve competitiveness and create value-added products, as is the case in the observed Central European countries.

The fact that the competitiveness of $\mathrm{RS}^{\prime} \mathrm{s}$ manufacturing industry is very weak is confirmed by the fact that it comes bottom in almost every category (according to the competitive industrial performance

Table 10 Production trends in the manufacturing industry, 2006-2013

\begin{tabular}{|c|c|c|c|c|c|c|}
\hline \multirow[b]{2}{*}{ Country } & \multicolumn{3}{|c|}{ GVA per employee, in EUR } & \multirow{2}{*}{$\begin{array}{l}\text { Average } \\
\text { growth rate } \\
\text { of GVA per } \\
\text { employee }\end{array}$} & \multirow{2}{*}{$\begin{array}{l}\text { Average } \\
\text { employee } \\
\text { growth rate }\end{array}$} & \multirow{2}{*}{$\begin{array}{l}\text { Average GVA } \\
\text { growth rate }\end{array}$} \\
\hline & 2006 & 2013 & Change & & & \\
\hline Bulgaria & $\mathrm{N} / \mathrm{A}$ & $\mathrm{N} / \mathrm{A}$ & $\mathrm{N} / \mathrm{A}$ & $N / A$ & $-1,7$ & $\mathrm{~N} / \mathrm{A}$ \\
\hline Czech Republic & 21,573 & 26,627 & 5,054 & +3.3 & -0.3 & +5.1 \\
\hline Croatia & 17,137 & 19,634 & 2,497 & +2.0 & -1.8 & -1.5 \\
\hline Hungary & 20,299 & 25,095 & 4,796 & +3.4 & -2.0 & +0.1 \\
\hline Slovakia & 18,945 & 28,943 & 9,998 & +7.0 & -0.9 & +5.9 \\
\hline Slovenia & 28,308 & 37,086 & 8,778 & +4.1 & -2.8 & +0.8 \\
\hline The Republic of Serbia & 8,251 & 19,197 & 10,946 & +13.3 & -5.0 & +3.2 \\
\hline
\end{tabular}

Source: Author, based on: The Eurostat data, 2015; UNECE, 2015; SOR, 2015 
ranking, RS ranks the $73^{\text {rd }}$ out of the 136 ranked world industries and the $34^{\text {th }}$ out of the 38 ranked industries in Europe in 2013 (Figure 3)). All the other countries included in the present research have a higher level of competitiveness, which is certainly due to their more efficient industrial development.

UNIDO's CIP index (Competitive Industrial Performance Index) is the indicator that can be used to measure and analyze the industrial competitiveness of a country. This index measures a country's performance on the interval scale from 0 to 1 . Additionally, it also indicates the productivity rate and the implemented structural change. It is a composite index that measures the capacity of the manufacturing industry to produce and export competitive products. Several options are available for calculating the CIP; however, the linear aggregate method applies the following formula (UNIDO, 2013b):

$$
C I P_{j t}=\sum_{i=1}^{q} w_{i} I_{i j t}
$$

Here, CIP ${ }_{j t}$ is the index of the country $j$ in the year $t$. The weighting factor $w_{i}$ relates to the $i$ indicators, while the sum of all weighting factors is 1 . The weighting factors $w_{i}$ take the value $1 / 6$ for the indicators MVApc, MXpc, ImWMVA and ImWMT, and the value 1/12 for the indicators MHVAsh, MVAsh, MHXsh and MXsh. $I_{i j t}$ is the value of the indicator $i$ for the country $j$ in the year $t$. According to the linear method, $I_{i j t}$ is calculated as $\left(X_{i j t}-\min X_{i j t}\right) /\left(\max X_{i j t}-\min X_{i j t}\right)$. $X_{i j t}$ is the value of the indicator $i$ for the country $j$ in the year $t$, where the min (max) are the values of the analyzed indicator in the sample of the surveyed countries (UNIDO, 2013b).

In comparison with the other countries observed, the CIP index of RS's manufacturing industry was 0.031 in 2013 (Figure 4). All of the analyzed countries had the significantly greater values of the CIP index, which means that they had higher productivity rates as well as the intensity of structural changes. This confirms that the levels of the development and competitiveness of the industry in RS and the rest of the countries observed are in correlation with their industrialization intensity.

Such a correlation is further supported by the high value of Pearson's correlation coefficient of these seven countries regarding the newly created value, the CIP index, the exports and the intensity of industrialization in 2013 (Table 11). This is especially evident concerning

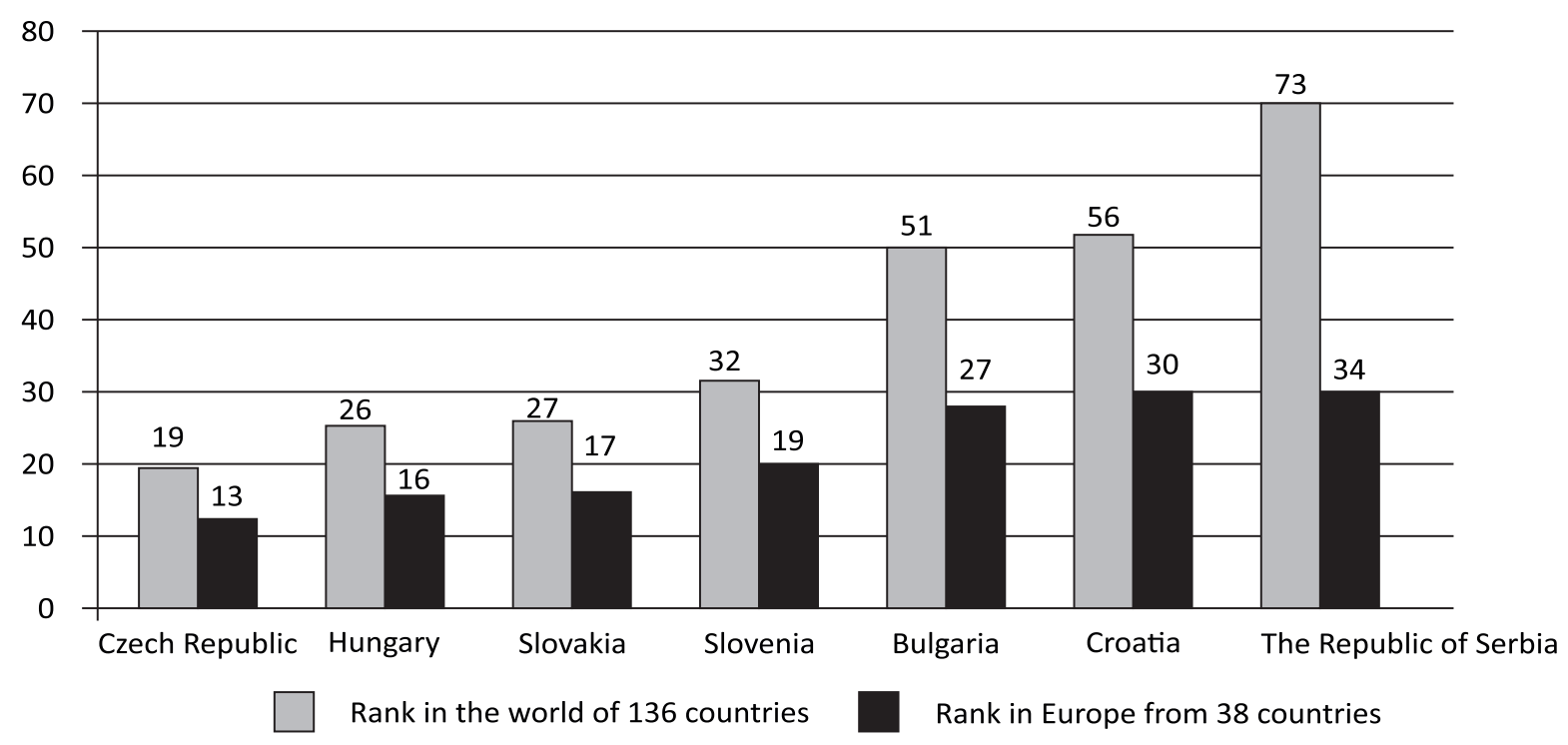

Figure 3 The competitive industrial performance ranking of the observed countries in 2013 


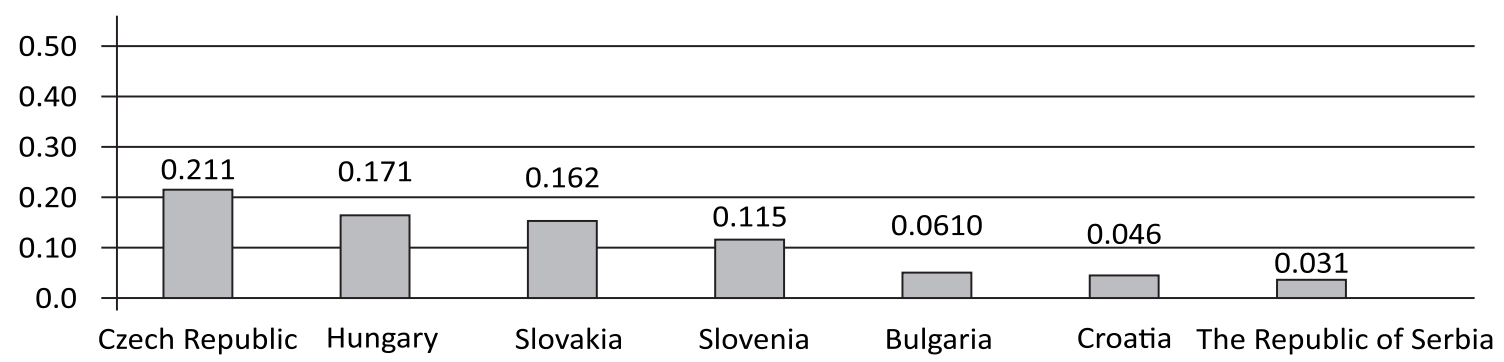

Figure 4 The value of the CIP index of the countries surveyed in 2013

Source: Author, based on: UNIDO, 2013b

the value of the medium- and high-tech manufacturing value added share in the total manufacturing value added (MHVAsh).

This also confirms that qualitative structural change, the transfer of knowledge, technological complexity and modernization, i.e. the magnitude of the shift from the traditional products to the new ones characterized by a greater productivity, competitiveness and the value-added created, all affect the attained intensity of industrialization. In the case of RS, the low value added per capita and the low value of the composite CIP index, indicate a high correlation between the low development level, low competitiveness and the low intensity of the structural changes concerning the propulsive production activities.

\section{The necessity of structural changes in the major production and export activities}

There are three of the twenty-four sectors of the manufacturing industry in RS that generate $50 \%$ of value-added products. The main sectors are food, beverages and tobacco (33\%), manufactures of metals $(9 \%)$ and coke and petroleum products $(8 \%)$. The structure of the production of the manufacturing industry shows that it is based on resource and laborintensive products and the products of the low- and medium-low technological intensity (Table 12). In addition to the low level of finalization, these products are of low productivity and low value-added features. This confirms the economic rule that, at a lower level of labor productivity, the production offer is limited to exactly this type of products.

The data on the distribution of the GVA according to the three major production sectors illustrate the differences in the production structure of the manufacturing industry in RS and the observed countries. The principal manufacturing sectors in the mentioned countries are: road vehicles, machinery and equipment, chemicals and chemical products, electrical machinery and apparatus and manufactures of metals. These products are of medium hightechnology and medium low-technology concerning the labor intensity and know-how. These are the

Table 11 Pearson's correlation coefficient of the seven observed countries in 2013

\begin{tabular}{|c|c|c|c|c|c|c|}
\hline $\begin{array}{l}\text { MVApc and } \\
\text { VAsh }\end{array}$ & $\begin{array}{c}\text { MVApc and } \\
\text { MHVAsh }\end{array}$ & CIP and MVAsh & $\begin{array}{l}\text { CIP and } \\
\text { MHVAsh }\end{array}$ & MVApc and CIP & $\begin{array}{c}\text { MXpc and } \\
\text { MVAsh }\end{array}$ & $\begin{array}{l}\text { MXpc and } \\
\text { MHVAsh }\end{array}$ \\
\hline 0.8288 & 0.8327 & 0.7009 & $0.8798^{*}$ & $0.8794^{*}$ & 0.8716 & 0.8543 \\
\hline
\end{tabular}

Correlation is significant at the 0.05 level (2-tailed); * Correlation is significant at the 0.01 level (2-tailed) 
Table 12 The share of the three major production activities in the GVA in 2013

\begin{tabular}{l|lll}
\hline Country & Section - SITC Rev. 4 & Total & Technology intensity - OECD \\
\hline Bulgaria & $\begin{array}{l}\text { Food, beverages and tobacco (18\%) } \\
\text { Machinery and equipment(11\%) } \\
\text { Textile, clothes, leather (10\%) }\end{array}$ & $39 \%$ & $\begin{array}{l}\text { Low (28\%) and medium-high (11\%) } \\
\text { technology intensity }\end{array}$ \\
\hline Czech Republic & $\begin{array}{l}\text { Road vehicles (18\%) } \\
\text { Manufactures of metals (11\%) } \\
\text { Machinery and equipment (10\%) }\end{array}$ & $39 \%$ & $\begin{array}{l}\text { Medium-high (28\%) and medium- } \\
\text { low (11\%) technology intensity }\end{array}$ \\
\hline Croatia & N/A & N/A & N/A \\
\hline Hungary & $\begin{array}{l}\text { Road vehicles (17\%) } \\
\text { Machinery and equipment (16\%) } \\
\text { Food, beverages and tobacco (11\%) }\end{array}$ & $44 \%$ & $\begin{array}{l}\text { Medium-high (33\%) and low (11\%) } \\
\text { technology intensity }\end{array}$ \\
\hline \multirow{3}{*}{ Slovakia } & $\begin{array}{l}\text { Road vehicles (17\%) } \\
\text { Machinery and equipment (12\%) } \\
\text { Electrical machinery (9\%) }\end{array}$ & $38 \%$ & $\begin{array}{l}\text { Medium-high technology intensity } \\
(38 \%)\end{array}$ \\
\hline Slovenia & $\begin{array}{l}\text { Chemical products (17\%) } \\
\text { Manufactures of metals (14\%) } \\
\text { Machinery and equipment (11\%) }\end{array}$ & $42 \%$ & $\begin{array}{l}\text { Medium-high (28\%) and medium- } \\
\text { low (14\%) technology intensity }\end{array}$ \\
\hline \multirow{2}{*}{ The Republic of Serbia } & $\begin{array}{l}\text { Food, beverages and tobacco (33\%) } \\
\text { Manufactures of metals (9\%) } \\
\text { Coke and petroleum products (8\%) }\end{array}$ & $50 \%$ & $\begin{array}{l}\text { Low (33\%) and medium-low (17\%) } \\
\text { technology intensity }\end{array}$ \\
\hline
\end{tabular}

Source: Author, based on: UNIDO, 2015; Eurostat, 2015

propulsive sectors of production, which are important for employment and technological progress. These sectors also have a greater impact on productivity growth and competitiveness and also generate a higher added value, which further affects their export potential.

Based on the SITC, Rev. 4 and concerning the structure of exports from RS, the largest share belongs to the products listed in Section 7 (machinery and transport equipment 31\%), then Section 6 (manufactured goods classified chiefly by material 20\%) and finally Section 0 and Section 1 (food and live animals, and beverages and tobacco 17\%) (Table 13). Section 7 has recorded growth since 2012, especially the Sub-Section of road vehicles (including air-cushion vehicles). This structure does not follow the structure concerning the participation in the creation of the GVA, which is due to the fact that export follows cyclical trends in the global market and, more importantly, the fact that the major part of the technologically complex components used in car production are imported. The potential for an increase in the GVA lies in the domestic production of the components that are imported. This would cause a spillover effect to the other sectors, i.e. the production of technologically intensive machinery specialized for particular industries and electrical machinery and appliances, as is the case in the other surveyed countries.

The three leading export sectors, according to the SITC, Rev. 4, point to the unfavorable structure and volume of RS's exports, especially in comparison with the Czech Republic, Slovakia and Hungary. The structure of the exports of these countries is dominated by the production of road vehicles and passenger cars, specialized machinery and data processing, electrical machinery, apparatus and appliances, which all require the use of advanced technology and highly-qualified labor, which is not the case in RS. With its current production and export structure, RS could not compete with the other observed countries. Therefore, future 
reindustrialization should be followed by increased labor productivity in the existing manufacturing activities as well as a shift in the production orientation towards highly value-added products.

Table 13 Exports from the three major production activities - the share and the volume in 2013

\begin{tabular}{|c|c|c|c|}
\hline Country & $\begin{array}{l}\text { SITC. Rev. } 4 \\
\text { Sectors }\end{array}$ & Share \% & $\begin{array}{l}\text { Value in } \\
\text { million USD }\end{array}$ \\
\hline \multirow{3}{*}{ Bulgaria } & Sector 6 & $22 \%$ & 6,494 \\
\hline & Sector 7 & $18 \%$ & 5,197 \\
\hline & Sector 3 & $15 \%$ & 4,346 \\
\hline \multirow{3}{*}{ Czech Republic } & Sector 7 & $54 \%$ & 87,095 \\
\hline & Sector 6 & $17 \%$ & 28,058 \\
\hline & Sector 8 & $12 \%$ & 18,723 \\
\hline \multirow{3}{*}{ Croatia } & Sector 7 & $24 \%$ & 2,813 \\
\hline & Sector 6 & $16 \%$ & 1,879 \\
\hline & Sector 3 & $15 \%$ & 1,735 \\
\hline \multirow{3}{*}{ Hungary } & Sector 7 & $52 \%$ & 56,353 \\
\hline & Sector 6 & $12 \%$ & 11,460 \\
\hline & Sector 5 & $12 \%$ & 11,380 \\
\hline \multirow{3}{*}{ Slovakia } & Sector 7 & $57 \%$ & 48,844 \\
\hline & Sector 6 & $17 \%$ & 14,595 \\
\hline & Sector 8 & $9 \%$ & 7,371 \\
\hline \multirow{3}{*}{ Slovenia } & Sector 7 & $36 \%$ & 10,201 \\
\hline & Sector 6 & $21 \%$ & 6,000 \\
\hline & Sector 5 & $18 \%$ & 5,275 \\
\hline \multirow{3}{*}{$\begin{array}{l}\text { The Republic of } \\
\text { Serbia }\end{array}$} & Sector 7 & $31 \%$ & 2,417 \\
\hline & Sector 6 & $20 \%$ & 2,913 \\
\hline & Sector $0+1$ & $17 \%$ & 4,541 \\
\hline
\end{tabular}

Note: Sector 0 - Food and live animals; Sector 1 - Beverages and tobacco; Sector 3 - Mineral fuels, lubricants and related materials; Sector 5 - Chemicals and related products; Sector 6 - Manufactured goods classified chiefly by material; Sector 7 - Machinery and transport equipment; Sector 8 - Miscellaneous manufactured articles
Source: Author, based on: UNIDO, 2015; Eurostat, 2015

\section{CONCLUSION}

Numerous theoretical analyses as well as the economic reality show that industrialization stands as an imperative for successful economic development. Industrialization triggers structural change especially in developing countries. The results achieved in terms of the industrial development prior to the onset of the transition are significant. However, instead of bringing about the qualitative advancement, the beginning of the economic transition in RS marked the outbreak of the profound crisis in industrial development, which has continued to this day. The low rate of growth shows that the crisis in the industry is of a structural nature and that, in such an environment, any shift towards a propulsive production structure is a difficult task to do.

Structural change in the economy and intensive deindustrialization are not the results of industrial maturity and its developed structure. The sudden and premature deindustrialization as well as the implemented concept of transitional reforms and economic development strategies, have led to the devastation of the industry. The first hypothesis that it is necessary to implement structural change and reindustrialization in the Serbian industry is confirmed by the value of the achieved level of the economic development measured by the GDP per capita. In 2013, it accounted for $90 \%$ of the level achieved in 1990 .

The achieved level of the industrial development of RS is very low, especially in comparison with the Czech Republic, Slovakia, Hungary and Slovenia. According to the level of its industry's development, RS is in the group of the least developed industries in Europe and therefore amongst the least developed economies. The country's production capacity, level of technological development, industrialization intensity and export quality are showing a decreasing trend, causing further deindustrialization and thus affecting the low level of productivity and the competitiveness of the industry. 
The second hypothesis in this paper, that the level of the development and competitiveness of the industry in RS and the other observed countries is in a direct correlation with the intensity of industrialization, is confirmed by the level of labor productivity and competitiveness. The high growth of labor productivity expressed through the GVA per employee is unsustainable because it is not the result of the shift towards higher value-added production but rather a large decrease in the number of employees. The low value added per capita and the low value CIP index relating to the manufacturing industry means a high positive correlation between the low level of development and low competitiveness, on the one hand, and the low intensity of structural changes, on the other.

The main contribution of this paper lies in its critical examination of deindustrialization, structural changes, levels of the development and competitiveness of the industry as well as in its stressing the importance of the reindustrialization of RS. The primary goal of reindustrialization is the growth of industrial competitiveness that would ensure the growth of production, employment, exports, and, most importantly, improve the overall standard of living. With respect to the presented facts and problems of the industry, reindustrialization certainly brings many challenges and requires a lot of effort and investment.

The key limitation in this study is the availability of adequate and comparable data for a sufficiently long period of time, i.e. the data concerning the lower classification levels of the industry, such as branches or groups. This excludes the possibility of applying other complex indicators that are also used to measure the intensity of structural changes in an industry.

The structure of manufacturing production and exports at the sectoral level shows that this structure mainly includes low value-added products. This confirms the economic rule that, at a lower level of labor productivity, supply is limited to exactly this kind of products. Therefore, examining the correlation between the comparative advantage and change in the production structure as well as the impact of structural change on exports and investment in the Republic of Serbia can be considered as the subject matter of further research.

The findings of this research are also significant for policy makers and the main agents of the economic and industrial policy. The paper underlines that sustainable economic development and the channeling of the process regarding change in the industrial structure, especially in times of crisis, which is currently deeply rooted in the Serbian industry, is impossible without a comprehensive and consistent industrial policy. How successful a country will be in solving the aforementioned challenges is determined by its willingness to create a new development strategy and industrial policy; however, this should not be mistaken for a typical state intervention.

The important message this research sends to industrial policy makers is that this policy should be active and sophisticated in order to influence continued structural changes, the transfer and development of advanced technologies, the development of small, medium-sized and large enterprises as well as develop and implement the export strategy, which is a prerequisite for economic development and combating unemployment, as the burning issues of the society. Such a concept of the industrial policy can influence the creation of a more propulsive structure and a higher value-added industry, which is necessary for the more efficient performance on the global market.

It is essential that, due to the devastated industry, the creators of the industrial policy should initiate continuous structural changes. Such continuous structural changes are conditioned by the creation of a healthy business environment, macroeconomic stability, the availability of capital, by investing in education and the training of required staff, investing in research and development, improving the physical and intangible infrastructure and promoting domestic firms on foreign markets.

\section{REFERENCES}

Aiginger, K. (2014). Industrial Policy for a sustainable growth path. Policy Paper no 13, WWWforEurope. 
Doyle, E. (1997). Structural change in Ireland: The contribution of sectoral employment distribution to labour productivity convergence between Ireland and the EU: 1970-1990. Journal of Economic Studies, 24(1/2), 59-71.

European Bank for Reconstruction and Development (EBRD). (29. January 2015). Statistical databases. Retrieved 29. January 2015, from http://www.ebrd.com/what-we-do/economicresearch-and-data/data.html.

Eurostat. (29. January 2015). Statistical databases. Retrieved 29. January 2015, from http://ec.europa.eu/eurostat/data/ database.

Fagerberg, J. (2000) Technological progress, structural change and productivity growth: a comparative study. Structural Change and Economic Dynamics, 11(4), 393-418.

Jakopin, E. (2012). Post-crisis reallocation of growth factors. Economic Horizons, 14(2), 79-90. doi: 10.5937/ekonhor1202077J

Kollmeyer, C. (2009). Explaining Deindustrialization: How Affluence, Productivity Growth, and Globalization Diminish Manufacturing Employment. American Journal of Sociology, 114(6), 1644-1674.

Kucera, D., \& Milberg, W. (2003). Deindustrialization and changes in manufacturing trade: Factor content calculations for 1978-1995. Review of World Economics, 139(4), 601-624.

Lin, J., \& Chang, H. J. (2009). Should Industrial Policy in Developing Countries Conform to Comparative Advantage or Defy it? Development Policy Review, 27(5), 483-502. doi. org/10.1111/j.1467-7679.2009.00456.x

Lin, Y. J. (2012). New Structural Economics: A Framezwork for Rethinking Development and Policy. Washington: The World Bank. doi: 10.1596/978-0-8213-8955-3

Mickiewicz, T., \& Zalewska, A. (2005). De-industrialisation and the post-communist transition: Rowthorn and Wells' model revisited. Economics Working Papers 59, Centre for the Study of Economic and Social Change in Europe, SSEES, UCL: London, UK.

Naude, W., Szirmai, A., \& Lavopa, A. (2013). Industrialization lessons from BRICS: A comparative analysis. IZA Discussion Paper No.7543, University of Maastricht, The Netherlands.

Pack, H., \& Westphal, L. E. (1986). Industrial strategy and technological change: Theory versus reality. Journal of development economics, 22(1), 87-128.

Palma, J. G. (2008). Deindustrialisation, Premature Deindustrialisation, and the Dutch Disease'. In S. N. Durlauf, \& L. E. Blume, (Eds.), The New Palgrave: A Dictionary of Economics, 2nd edition. Basingstoke: Palgrave Macmillian,

\section{pp. 7-23. doi:10.1057/9780230226203.0369}

Republički zavod za statistiku. (2015). Statistička baza podataka

Rodrik, D. (2007). Industrial development: Some stylized facts and policy directions. Industrial Development for the 21st century: Sustainable Development Perspectives, New York, NY: United Nations. 7-28.

Rodrik, D. (2008). Normalizing industrial policy. Commission on growth and development working paper No. 3. Washington: World Bank. Retrieved June 1, 2009, from http://documents. worldbank.org/curated/en/2008/01/13163290/normalizingindustrial-policy

Rodrik, D. (2009). Industrial policy: don't ask why, ask how. Middle East Development Journal, 1(1), 1-29.

Rowthorn, R., \& Coutts, K. (2004). De-industrialisation and the balance of payments in advanced economies. Cambridge Journal of Economics, 28(5), 767-790. doi: 10.1093/cje/beh034

Syrquin, M. (2007). Structural Change and Development. In A. K. Dutt, \& J. Ros, (Eds.), International Handbook of Development Economics, Vol. 1, UK: Edward Elgar Publishing.

Szirmai, A. (2012). Industrialisation as an engine of growth in developing countries, 1950-2005. Structural Change and Economic Dynamics, 23(4), 406-420.

Szirmai, A., Naude, W., \& Alcorta, L. (2013). Introduction and Overview: The Past, Present and Future of Industrialization. In A. Szirmai, W. Naude, \& L. Alcorta, (Eds.), Pathways to Industrialization in the Twenty-First Century-New Challenges and Emerging Paradigms. Oxford: Oxford University Press. doi:10.1093/acprof:oso/9780199667857.003.0001

Tregenna, F. (2009). Characterising Deindustrialisation: An Analysis of Changes in Manufacturing Employment and GDP Internationally. Cambridge Journal of Economics, 33(3), 433-466.

Tregenna, F. (2011). Manufacturing productivity, deindustrialization, and reindustrialization. WIDER Working Paper 57, United Nations University, World Institute for Development Economics Research.

UNIDO. (2013a). Industrial Development Report 2013, Sustaining Employment Growth: The Role of Manufacturing and Structural Change. Vienna.

UNIDO. (2013b). The Industrial Competitiveness of Nations Looking back, forging ahead. Vienna.

United Nations Economic Commission for Europe (UNECE). 1. February 2015, Statistical databases. Retrieved 1. February 
2015, from http://www.unece.org/stats/econ.html

United Nations Industrial Development Organization (UNIDO). (29. January 2015). Statistical databases. Retrieved 29. January 2015, from http://www.unido.org/en/resources/ statistics /statistical-databases.html

Wade, R. H. (2012). Return of industrial policy? International Review of Applied Economics, 26(2), 223-239. doi:10.1080/02692 171.2011.640312

$$
\begin{array}{r}
\text { Received on } 26^{\text {th }} \text { February } 2015, \\
\text { after revision, } \\
\text { accepted for publication on } 6^{\text {th }} \text { April } 2015 . \\
\text { Published online on } 21^{\text {st }} \text { April } 2015
\end{array}
$$

Vladimir Micic is an Assistant Professor at the Faculty of Economics, University of Kragujevac, Kragujevac, the Republic of Serbia, where he received his $\mathrm{PhD}$ degree in Economics. He teaches the subjects of the Economics of Industry, Economic Development and the Economics of Growth and Development. His research interests include relevant issues of industrial policy, competitiveness and economic development. 


\title{
PONOVNA INDUSTRIJALIZACIJA I STRUKTURNE PROMENE U FUNKCIJI EKONOMSKOG RAZVOJA REPUBLIKE SRBIJE
}

\author{
Vladimir Mićić* \\ Ekonomski fakultet Univerziteta u Kragujevcu
}

\begin{abstract}
U radu se analiziraju industrijalizacija i strukturne promene koje ona izaziva, a koje su glavni pokretači i nosioci održivog ekonomskog razvoja. Ukazuje se da je industrija Republike Srbije (RS) devastirana, usled nagle i prevremene tercijarizacije, kao i neadekvatnih reformi. Postojeća struktura privrede i industrije nisu u stanju da obezbede održiv ekonomski razvoj. Shodno tome, cilj istraživanja je da se ukaže na značaj sprovođenja ponovne industrijalizacije i strukturnih promena u RS. Polazeći od stava da je industrija pokretač i nosilac ekonomskog rasta i razvoja, $u$ radu se ukazuje na to da je u RS neophodno sprovesti ponovnu industrijalizaciju i strukturne promene industrije, s obzirom na to da su nivo razvoja i konkurentnost industrije u korelaciji sa intenzitetom industrijalizacije. Rezultati istraživanja ukazuju na to da razvijenije industrijske zemlje imaju efikasnije strukturne promene i propulzivniju proizvodnju, koja stvara veću dodatu vrednost. Pored nivoa industrijskog razvoja, to se odražava na dostignuti nivo konkurentnosti, obim i kvalitet izvoza.
\end{abstract}

Ključne reči: industrijalizacija, strukturne promene, nivo razvoja i konkurentnost industrije, ekonomski razvoj

JEL Classification: L16, N1, O14, O25, O47

\section{UVOD}

Ekonomska istorija razvijenih zemalja, kao i brzo rastućih ekonomija BRICS (Brazil, Rusija, Indija, Kina i Južna Afika), potvrdila je da industrija ima ulogu pokretača i nosioca njihovog ekonomskog razvoja. Istovremeno, u dosadašnjem toku globalne ekonomske krize, pokazalo se da su upravo zemlje sa razvijenim industrijama bile manje izložene dejstvu njenih

*Korespondencija: V. Mićić, Ekonomski fakultet Univerziteta u Kragujevcu, Đ. Pucara 3, 34000 Kragujevac, Republika Srbija; e-mail: micicv@kg.ac.rs negativnih efekata. Ekonomska kriza potvrdila je da nema značajnijeg ekonomskog napretka bez razvijene industrije $\mathrm{i}$ kontinuiranih strukturnih promena $\mathrm{u}$ njoj. Prednost industrijskog razvoja jeste $u$ tome što on zahteva stalne promene industrijske strukture, što je od posebnog značaja za zemlje sa niskim nivoom kapaciteta proizvodnje, izvoza i intenziteta industrijalizacije. Istovremeno, strukturne promene su nužnost $\mathrm{u}$ uslovima dinamičnog razvoja nauke, znanja i tehničko - tehnoloških inovacija, pa ekonomski rezultati zavise od brzine i efikasnosti njihovog sprovođenja. 
Industrija Republike Srbije duže vreme se nalazi u dubokoj krizi, a globalna ekonomska kriza je pojačala i učinila uočljivijim sve slabosti ekonomskog i industrijskog razvoja. U tranzicionom periodu došlo je do deindustrijalizacije privrede i devastacije industrije, što je ekonomski rast i razvoj učinilo neodrživim. Iskustva i prakse razvijenih zemalja, brzorastućih ekonomija BRICS-a i naprednih tranzicionih zemalja, iz dalje i bliže prošlosti, pokazuju da je, u cilju ostvarenja stabilnog ekonomskog razvoja, potrebna ponovna industrijalizacija i reindustrijalizacija RS. Industrijalizacija je neophodna zato što su pojedine aktivnosti devastirane i zahtevaju da se krene od samog početka, a reindustrijalizacija je nužna kako bi propulzivnija struktura povećala nivo i konkurentnost industrije.

Stoga je predmet istraživanja $u$ ovom radu industrijalizacija RS i strukturne promene, koje treba da budu u funkciji efikasnog industrijskog razvoja, ali i održivog razvoja privrede $u$ celini. Ponovna industrijalizacija je put za izlazak iz ekonomske krize i način uspešne realizacije brojnih društvenoekonomskih ciljeva.

$\mathrm{Na}$ osnovu relevantnih saznanja o stanju devastiranosti industrije i niskom nivou BDP per capita RS, cilj istraživanja $\mathrm{u}$ ovom radu je da se ukaže na značaj efikasnog sprovođenja ponovne industrijalizacije i strukturnih promena, kao uslova održivosti ekonomskog i društvenog razvoja. Kako bi se ukazalo na značaj ponovne industrijalizacije, porede se rezultati razvoja i strukturnih reformi privrede i industrije RS sa zemljama koje su u procesu industrijalizacije (Bugarska i Hrvatska), kao i sa grupom industrijalizovanih zemalja (Češka, Slovačka, Mađarska i Slovenija). Radi se o zemljama, koje su, izuzev Bugarske, na višem nivou ekonomskog razvoja od RS, izraženo BDP per capita.

U skladu sa postavljenim predmetom i ciljem istraživanja, u radu se polazi od sledećih hipoteza:

H1: S obzirom na to da je industrija pokretač i nosilac ekonomskog rasta i razvoja, u Republici Srbiji je neophodno sprovesti ponovnu industrijalizaciju i strukturne promene industrije.

$\mathrm{H} 2$ : Nivo razvoja i konkurentnost industrije su $\mathrm{u}$ korelaciji sa intenzitetom industrijalizacije.
U cilju potvrde postavljenih hipoteza, koriste se indikatori razvoja i strukturnih promena (stope i indeksi rasta proizvodnje, učešće sektora u BDP, BDV (bruto dodata vrednost) i zaposlenosti, BDV prerađivačkeindustrije po zaposlenom, obim istruktura izvoza industrije prema tehnološkoj intenzivnosti i Standardnoj međunarodnoj trgovinskoj klasifikaciji, Revizija 4 (SMTK, Rev. 4). Za uporednu analizu industrijskih performansi i strukturnih promena Bugarske, Češke, Hrvatske, Mađarske, Slovačke, Slovenije i Republike Srbije primenjen je komparativni naučni metod, kako bi se došlo do saznanja bitnih za pokretanje ponovne industrijalizacije. Metodologija organizacije Ujedinjenih nacija za industrijski razvoj (UNIDO metodologija) relevantna je za ocenu stepena industrijalizacije i konkurentnosti industrije. Korelaciona analiza koristi se za utvrđivanje prirode i forme povezanosti između dostignutog stepena razvoja, konkurentnosti i intenziteta industrijalizacije.

Rad je strukturiran $\mathrm{u}$ osam delova. U drugom delu daje se pregled literature o industrijalizaciji i strukturnim promenama. U trećem delu analizirani su tempo i kriza razvoja industrije RS u periodu tranzicije. Četvrti deo razmatra iskustvo prevremene i nagle deindustrijalizacije privrede i devastacije industrije RS. Sagledavanje dostignutog nivoa razvoja industrije RS i posmatranih zemalja izloženo je $u$ petom delu, dok šesti deo sadrži rezultate istraživanja konkurentnosti industrija $\mathrm{u}$ analiziranim zemljama. $\mathrm{U}$ sedmom delu rada data je analiza glavnih proizvodnih i izvoznih aktivnosti koje impliciraju nužnost strukturnih promena industrije RS. Zaključak, stavovi o hipotezama, doprinos i ograničenja istraživanja prezentirani su u osmom delu rada.

\section{PREGLED LITERATURE}

Industrijalizacija, koja od prve industrijske revolucije traje preko 250 godina, najčešće se posmatra kao strategija ekonomskog razvoja. Ona ima različite specifičnosti $\mathrm{i}$ puteve sprovođenja $\mathrm{u}$ različitim zemljama, zavisno od nivoa razvoja i trenutka kada je započeta (Pack \& Westphal, 1986). Ona je sinonim za ekonomski razvoj, bogatstvo, tehnološko vođstvo i inovacije, ekonomsku i političku moć, i međunarodnu 
dominaciju (Szirmai, Naude \& Alcorta, 2013). Razvoj industrije smatra se ključnim pokretačem strukturnih promena i transformacija privreda, što je od posebnog značaja za zemlje u razvoju. Uporedo sa promenom strukture privrede, i promenama učešća industrije $\mathrm{u}$ zaposlenosti i BDP, menja se i struktura industrije, posebno prerađivačke. Intezitet promena je veći što je zemlja na nižem nivou razvijenosti.

Strukturne promene su promene $\mathrm{u}$ sastavu jednog agregata, koje utiču na relativni značaj sektora ili njegovih delova $\mathrm{u}$ privredi $\mathrm{i}$ fundamentalno $\mathrm{su}$ povezane sa ekonomskim razvojem (Syrquin, 2007). Podrazumevaju pomeranje od tradicionalnih ka novim visoko produktivnim aktivnostima (Rodrik, 2008). Pritom, nivo i dinamika produktivnosti veći su $\mathrm{u}$ industriji nego u drugim sektorima (Szirmai, 2012). Takođe, industrija utiče na rast produktivnosti drugih sektora, što je ključno za rast konkurentnosti, pa shodno tome, i za ekonomski rast i razvoj.

Strukturne promene industrije dovode do promene odnosa i transformacija u kompoziciji proizvodnih faktora, proizvodnje, zaposlenosti, ponude, tražnje, investicija i trgovine (Doyle, 1997). Tako uspostavljena fleksibilna proizvodna struktura je važan element rasta produktivnosti, s obzirom na to da omogućava efikasnu realokaciju resursa (Fagerberg, 2000; Jakopin, 2012).

Zemlje koje nisu uspele da sprovedu strukturne promene industrije zaostaju u razvoju i teško se udaljavaju od tradicionalne proizvodnje (Lin, 2012). Kod zemalja u razvoju, strukturne promene prerađivačkih industrija od tradicionalnih ka tehnološki složenim, sa većom produktivnošću i konkurentnošću i većom stvorenom dodatom vrednošću, uslov su povećnja intenziteta industrijalizacije. To je pretpostavka otvaranja novih radnih mesta i održivog ekonomskog razvoja. Kao glavni pokretači intenzivnijeg razvoja industrije i strukturnih promena u njoj, smatraju se: znanje, veštine, inovacije, tehnologije, tražnja, efikasnost resursa, investicije, veličina preduzeća, aktivnosti lanca vrednosti, aglomeracije i industrijska politika (UNIDO, 2013a).

Bitan činilac procesa industrijalizacije i strukturnih promena je industrijska politika. Činjenica je da je u industrijski razvijenim ekonomijama država pružala različitu podršku svojim industrijama tokom razvoja (Lin \& Chang, 2009). Glavni zadatak industrijske politike jeste, pored ispravljanja tržišnih neuspeha, pokretanje i ubrzavanje strukturnih promena (Sy rquin, 2007). Upravo brzo rastuće ekonomije zemalja BRICS-a, svoj uspon duguju industrijskoj politici koja je uticala na uspešan razvoj njihovih industrija, tehnoloških sposobnosti i konkurentnosti (Naude, Szirmai \& Lavopa, 2013). Očigledano da je razlog za razmatranje razvojne uloge države i aktivne i sofisticirane industrijske politike (Rodrik, 2007) podstaknut izgradnjom tehnološki konkurentnih industrija. U tom slučaju, industrijska politika usmerena je na poboljšanje poslovnog ambijenta i kontinuirane promene strukture industrije ka aktivnostima koji će obezbediti održiv ekonomski razvoj i društveno blagostanje (Rodrik, 2009; Wade, 2012; Aiginger, 2014).

Danas su glavni izazovi za mnoge zemlje deindustrijalizacija i reindustrijalizacija (Kucera \& Milberg, 2003; Palma, 2008; Tregenna, 2009). Industrijalizacija ostaje važan cilj za većinu zemalja $\mathrm{u}$ razvoju, posebno onih $\mathrm{u}$ tranziciji. Globalna ekonomska kriza učinila je ponovo aktuelnom industrijalizaciju u sadašnjim i budućim izazovima ekonomskog razvoja ovih zemalja. Ništa manje nije aktuelna njena uloga danas i u razvijenim zemljama, pre svega, zbog konkurencije brzo rastućih ekonomija.

Činjenica je da su mnoge razvijene privrede, sa višim nivoom BDP per capita, zapravo, deindustrijalizovane usled bržeg rasta produktivnosti $u$ industriji nego $u$ sektoru usluga, veće tražnje za uslugama od tražnje za proizvodima, kao i rasta trgovine između razvijenih i nerazvijenih zemalja (Kollmeyer, 2009). U njima, deindustrijalizacija pokazuje zrelost industrije i privredne strukture, a dominantno učešće grana sa visokim tehnologijama dovodi do toga da se gubi identitet klasične industrijske strukture (Tregenna, 2011).

Sa ovog aspekta, deindustrijalizacija se može posmatrati kao pozitivan, ali i kao negativan proces (Rowthorn \& Coutts, 2004). U pozitivnom kontekstu dolazi do bržeg rasta produktivnosti od proizvodnje, tako da se zaposlenost apsolutno i relativno smanjuje. Posledica ovih promena nije nezaposlenost. Višak 
iz industrije realocira se $u$ sektor usluga $u$ kojem se stvaraju nova radna mesta, čime se obebeđuje privredni rast. U suprotnom, deinudstrijalizacija dovodi do krupnih problema u ekonomskom razvoju, kao što je to slučaj sa zemaljama Centralne i Istočne Evrope (Mickiewicz \& Zalewska, 2005). Ona se pojavljuje znatno ranije, i na nižem nivou BDP per capita, nego u razvijenim zemljama.

U razvijenim zemljama, deindustrijalizaciju, istovremeno, prati i efikasna reindustrijalizacija. A u zemljama u razvoju, izazove predstavljaju prevremena deindustrijalizacija i reindustrijalizacija (Tregenna, 2011).

Ponovno povećanje učešća industrije $u$ BDP i zaposlenosti zahteva više napora nego što je to bio slučaj na početku, ili tokom industrijalizacije. Razlog je i promena razvojne paradigme prema kojoj uspešan razvojne zavisi samo od posedovanja prirodnih resursa, jeftine radne snage i kapitala. On zavisi i od faktora koji su osnova visoko sofisticirane reindustrijalizacije, jačanja uloge propulzivnih industrija i nastanaka novih tehnološki i znanjem intenzivnih proizvoda, kao i nastanka industrija usluga. Ovakvo kretanje od deindustrijalizacije ka reindustrijalizaciji ukazuje i na značaj i važnost industrijske politike, kojom se može uticati na kontinuirane strukturne promene.

\section{DINAMIKA RAZVOJA INDUSTRIJE}

Nivo razvijenosti privrede Republike Srbije posle Drugog svetskog rata, kao i republika članica SFRJ, uslovio je strategiju ekonomskog razvoja zasnovanu na opštoj industrijalizaciji, odnosno, model ubrzane industrijalizacije kao osnovne industrijske strategije. Cilj je bio brz i dinamičan razvoj privrede, a industrijalizacija je bila sredstvo za realizaciju širih društveno-ekonomskih ciljeva. Nosilac industrijalizacije bila je država, koja je više ekonomskom nego adekvatnom industrijskom politikom usmeravala sam proces razvoja industrije.

Mada je tempo industrijalizacije bio različit kroz različite periode razvoja industrije, ukupni ostvareni efekti industrijskog razvoja RS, mereni fizičkim obimom proizvodnje, su značajni na kraju osamdesetih godina XX veka (Slika 1). Sa BDP per capita od oko 1450 dolara (u stalnim cenama iz 2000. godine), u trenutku raspada bivše SFRJ, industrija RS dostigla je središnju i najdelikatniju fazu uravnoteženog razvoja. Brzi tempo rasta industrije uticao je na to da ona pruži najznačajniji doprinos privrednom rastu, učestvujući sa oko $44 \%$ u stvaranju ukupnog proizvoda.

Započeta tranzicija privrednog sistema, početkom devedesetih godina $X X$ veka, označava i početakizrazite krize $u$ razvoju industrije. Usporena tranzicija tokom

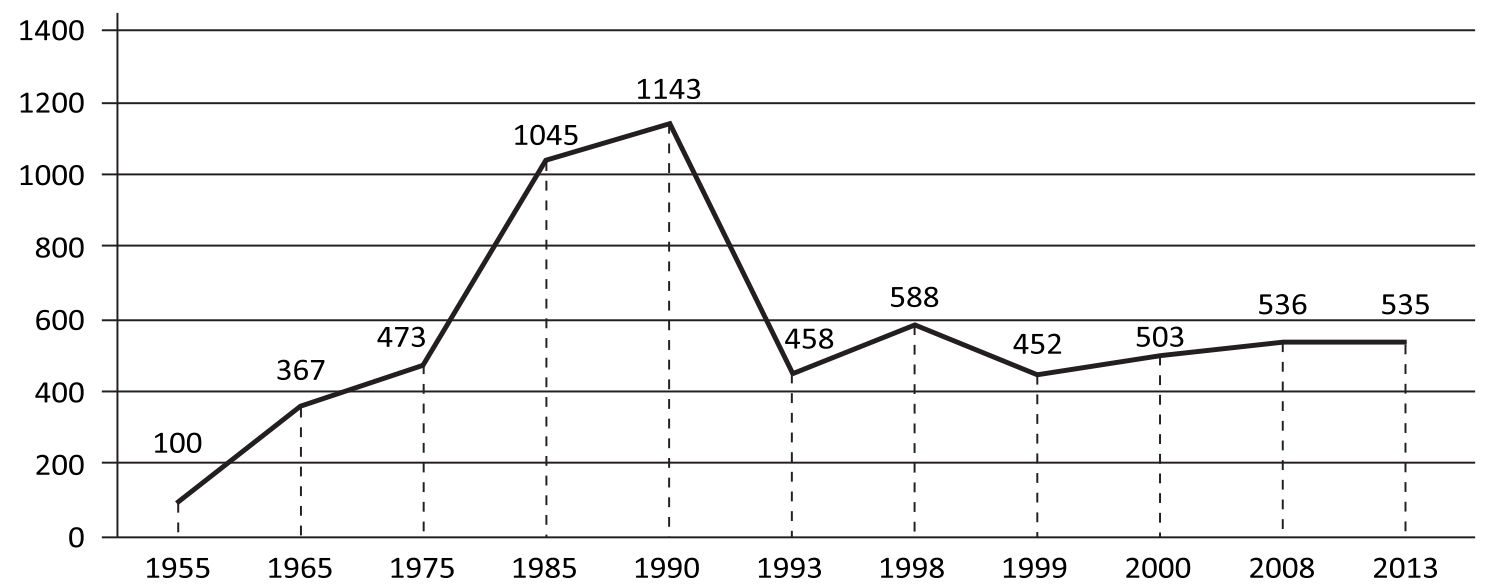

Slika 1 Indeks fizičkog obima industrijske proizvodnje 1955-2013. 
devedesetih i njeno intenziviranje posle 2000. godine, doveli su do drastičnog pada industrijske proizvodnje. Pad je rezultat usporene i neefikasne promene starog i izgradnje novog privrednog sistema i uticaja brojnih unutrašnjih i spoljnih ekonomskih i neekonomskih faktora. Industrijska proizvodnja prosečno je beležila pad od 7.5\% (BDP 5.5\%) u poslednjoj deceniji XX veka (Tabela 1). Za razliku od RS, anlizirane zemlje su beležile manji pad proizvodnje. Strukturne reforme industrije, posebno zemalja Centralne Evrope, postale su sastavni deo tranzicije njihovih privreda. Promene u strukturi proizvodnje rezultat su rasta domaćih i stranih investicija i realokacije kapaciteta iz razvijenih zemalja, kao i pristupa tržištu EU. Već u početnoj fazi tranzicije postalo je jasno da su strukturne promene industrije od suštinskog značaja kako bi se obezbedio njihov uspešan oporavak i rast.

Tabela 1 Prosečne stope rasta industrije, 1991-2000.

\begin{tabular}{l|ccc}
\hline Zemlje & 1991-2000. & 2001-2008. & 2009-2013. \\
\hline Bugarska & -5.7 & 7.0 & -2.1 \\
Češka & -1.7 & 5.5 & 0.1 \\
Hrvatska & 5.9 & 4.0 & -3.8 \\
Mađarska & 3.8 & 5.7 & -0.3 \\
Republika Srbija & -7.5 & 2.0 & -1.1 \\
Slovačka & -0.8 & 9.5 & 2.2 \\
Slovenija & -1.5 & 3.8 & -2.1 \\
\hline
\end{tabular}

Izvor: Autor, na osnovu: European Bank for Reconstruction and Development (EBRD), 2015

Republika Srbija je u prvoj deceniji XXI veka imala spor tempo rasta industrije, što je, uprkos povoljnim konjukturnim kretanjima pre 2008. godine, uticalo na to da ona zabeleži višestruko niže prosečne godišnje stope rasta $(2 \%)$ u poređenju sa posmatranim zemljama. Uzrok su tranzicione reforme i brojna sistemska ograničenja koja su dovela do nagle tercijarizacije privrede. Dodatno usporavanje proizvodnje nastaje kao rezultat kontrakcije privredne aktivnosti i pada izvozne tražnje od 2008. godine. Tempo rasta proizvodnje je negativan i daleko je ispod ostvarivanog rasta pre krize. Usporavanje privrednih, strukturnih i institucionalnih promena usled globalne ekonomske krize, utiče i na oporavak i tempo rasta proizvodnje.

Prema zvaničnim statističkim podacima, nivo industrijske proizvodnje u 2013. godini iznosi svega oko $50 \%$ od nivoa iz 1990. godine. Tačnije, nivo industrijske proizvodnje u 2013. nije prešao fizički obim proizvodnje iz 1998. godine (RZS. Statistička baza podataka, 2015). Uporedna analiza rasta fizičkog obima industrijske proizvodnje pokazuje da je on povećan u Slovačkoj za čak 86\%, u Češkoj i Mađarskoj za 45\%, u 2013. u odnosu na 2000. godinu. Istovremeno, nivo fizičkog obima industrijske proizvodnje u RS je povećan za svega $10 \%$ (Tabela 2).

Tabela 2 Indeks industrijske proizvodnje, 2000=100

\begin{tabular}{l|cc}
\hline Zemlje & 2001-2008. & 2001-2013. \\
\hline Bugarska & 155 & 145 \\
Češka & 144 & 145 \\
Hrvatska & 132 & 113 \\
Mađarska & 145 & 145 \\
Republika Srbija & 115 & 110 \\
Slovačka & 175 & 186 \\
Slovenija & 130 & 119 \\
\hline
\end{tabular}

Izvor: Eurostat, 2015

Tempo rasta industrije RS karakterišu sledeće dve činjenice. Prvo, industrija se u dužem periodu nalazi u dubokoj krizi, koja je strukturne, a ne ciklične prirode, zbog čega su neophodne značajne strukturne promene. Drugo, intenzivnije strukturne promene industrije, $\mathrm{u}$ smislu modernije i propulzivnije industrijske stukture, nisu ostvarene, jer je za njih potreban dinamičniji rast industrije.

\section{DEINDUSTRIJALIZACIJA PRIVREDE I DEVASTACIJA INDUSTRIJE}

Rast učešća sektora usluga, uz smanjenje udela realnog sektora $u$ proizvodnji i zaposlenosti, uobičajena su obeležja tranzicionog procesa, što 
je uticalo na deindustrijalizaciju $u$ privredi RS i posmatranim zemljama. Za razliku od RS, naprednije tranzicione zemlje su, istovremeno, započele i proces reindustrijalizacije, što je uticalo na to da one $u$ predkriznom periodu do 2008. godine, sa manje ili više uspeha, povećaju industrijsku proizvodnju. To je uticalo i na to da intenzitet strukturnih promena, na relaciji realne i uslužne delatnosti, bude nešto blaži u odnosu na privredu RS.

Veliki prosečan pad industrijske proizvodnje od 1990. do 2000. godine $(-7.5 \%)$, kao i njeno kretanje po prosečnoj stopi nižoj 3,5 puta od rasta BDP (oko 3\%) posle 2001. godine, doveli su do drastičnog smanjenja učešća industrije u strukturi BDP. U 2010. godini, ono je iznosilo 21.4\%, u 2001. učešće je bilo 30\%, a u 1991, oko $44 \%$ (Tabela 3). Znatno manji i usporeniji pad učešća industrije u BDP imaju posmatrane zemlje Centralne Evrope.

Analiza bruto dodate vrednosti (BDV), prema proizvodnom principu, pokazuje da je došlo do smanjenja učešća industrije, uz istovremeni rast usluga. U 2013. godini najveće učešće industrije u BDV ima Češka (28.7\%), dok su najveće smanjenje od 2001. godine zabeležile Slovačka (-3.2\%) i Republika Srbija (-2.6\%). Za razliku od RS, Bugarska ima rast učešća industrije u BDV (Tabela 4 i 5). Uočljivo je da Republika Srbija ima učešće sektora usluga na nivou Češke i Slovačke, ali i mnogo veći intenzitet njegovog rasta. Ovakvo kretanje učešća BDV industrije posledica je činjenice, da je njegova prosečna stopa rasta među najnižima
Tabela 3 Učešće industrije u BDP

\begin{tabular}{l|cccccc}
\hline & 1991. & 1996. & 2001. & 2006. & 2010. & $\begin{array}{c}\text { Promena } \\
1991-2010 .\end{array}$ \\
\hline Zemlje & 39.8 & 29.0 & 25.2 & 26.1 & 22.6 & -17.2 \\
Češka & 37.9 & 33.8 & 37.5 & 41.9 & 37.7 & -0.2 \\
Hrvatska & 21.5 & 20.2 & 19.0 & 17.7 & 19.5 & -2.0 \\
Mađarska & 21.0 & 23.5 & 26.4 & 26.1 & 26.8 & 5.8 \\
Republika Srbija & 44.4 & 26.0 & 30.0 & 21.8 & 21.4 & -23.0 \\
Slovačka & 35.2 & 29.5 & 25.8 & 28.3 & 25.3 & -9.9 \\
Slovenija & 36.0 & 25.4 & 25.9 & 23.8 & 24.2 & -11.8 \\
\hline
\end{tabular}

Izvor: Autor, na osnovu: EBRD, 2015; United Nations Economic Commission for Europe (UNECE), 2015

$(1.7 \%)$, a usluga (3.3\%) među najvišima od posmatranih zemalja. Za razliku od posmatranih zemalja, privreda RS zabeležila je pad učešća poljoprivrede i građevinarstva u BDV, odnosno, celog realnog sektora.

Broj radnika $\mathrm{u}$ industriji RS smanjen je kako apsolutno, tako i relativno. Ukupan broj zaposlenih $\mathrm{u}$ industriji smanjen je sa 674000 u 2001. na 337000 u 2013. Istovremeno, broj zaposlenih u prerađivačkoj industriji smanjen je za 317000 (RZS, 2015).

Sektorske promene zaposlenih karakteriše sve veći broj zaposlenih u sektoru usluga, što je slučaj i kod drugih posmatranih zemalja (Tabela 6). Ipak, u uslužnom

Tabela 4 Učešće sektora u BDV

\begin{tabular}{l|cccccccc}
\hline & $\begin{array}{r}\text { Sektori } \\
\text { proizvodni } \\
\text { princip }\end{array}$ & \multicolumn{2}{c}{ Poljoprivreda } & \multicolumn{2}{c}{ Industrija } & \multicolumn{2}{c}{ Građevinarstvo } & \multicolumn{2}{c}{ Usluge } \\
\cline { 3 - 9 } Zemlje & 2001. & 2013. & 2001. & 2013. & 2001. & 2013. & 2001. & 2013. \\
\hline Bugarska & 10.5 & 4.7 & 18.9 & 19.9 & 4.5 & 4.1 & 66.1 & 71.3 \\
Češka & 3.0 & 2.3 & 28.7 & 27.9 & 5.6 & 5.0 & 62.7 & 64.8 \\
Hrvatska & 5.3 & 3.6 & 19.4 & 17.9 & 4.6 & 4.5 & 70.7 & 74.0 \\
Mađarska & 4.9 & 3.7 & 22.5 & 22.1 & 4.7 & 3.3 & 67.9 & 70.9 \\
Republika Srbija & 17.8 & 7.9 & 25.0 & 22.4 & 4.3 & 4.3 & 52.9 & 65.4 \\
Slovačka & 4.5 & 3.7 & 25.8 & 22.6 & 5.7 & 7.8 & 64.0 & 65.9 \\
Slovenija & 2.6 & 1.8 & 25.2 & 23.1 & 5.4 & 4.6 & 66.5 & 70.5 \\
\hline
\end{tabular}


Tabela 5 BDV - prosečna stopa rasta i promena učešće (+/-), 2001-2013, \%

\begin{tabular}{lr|cccccccc}
\hline & $\begin{array}{r}\text { Sektori } \\
\text { proizvodni } \\
\text { princip }\end{array}$ & \multicolumn{2}{|c}{ Poljoprivreda } & \multicolumn{2}{c}{ Industrija } & \multicolumn{2}{c}{ Građevinarstvo } & \multicolumn{2}{c}{ Usluge } \\
\cline { 3 - 9 } Zemlje & Prosek & $(+/)$ & Prosek & $(+/)$ & Prosek & $(+/)$ & Prosek & $(+/-)$ \\
\hline Bugarska & -1.4 & -5.8 & 3.8 & +1.0 & 3.7 & -0.4 & 4.0 & +5.2 \\
Češka & -0.3 & -0.7 & 3.8 & -0.8 & 0.7 & -0.6 & 2.1 & +2.1 \\
Hrvatska & -0.8 & -1.7 & 0.5 & -1.5 & 2.3 & -0.1 & 2.3 & +3.3 \\
Mađarska & 3.5 & -1.2 & 1.4 & -0.4 & -0.1 & -1.4 & 2.0 & +3.0 \\
Republika Srbija & 1.9 & -9.9 & 1.7 & -2.6 & 4.5 & 0.0 & 3.3 & +12.5 \\
Slovačka & 6.8 & -0.8 & 6.1 & -3.2 & 4.6 & +2.1 & 3.4 & +1.9 \\
Slovenija & 0.3 & -0.8 & 1.7 & -2.1 & -0.7 & -0.8 & 2.3 & +0.8 \\
\hline
\end{tabular}

Izvor: Autor, na osnovu: Eurostat, 2015; UNECE, 2015; RZS, 2015

sektoru nije stvoreno dovoljno novih radnih mesta, da bi se ovako intenzivan pad iz industrije apsorbovao, tako da je deo radne snage iz industrije realociran u poljoprivredu. Podatak da je 2013. godine stopa nazaposlenosti oko 23\% (RZS, 2015), a da je učešće zaposlenih $\mathrm{u}$ industriji niže nego $\mathrm{u}$ poljoprivredi, govori o nivou ekonomskog razvoja, mestu industrije u razvoju i stanju u kome se ona nalazi.

U poređenju sa analiziranim zemljama, učešće zaposlenih u sektoru industrije je niže, dok je učešće zaposlenih u sektoru poljoprivrede na visokom nivou. Podaci pokazuju da je slična situacija u Bugarskoj. U
Češkoj i Slovačkoj učešće zaposlenih u poljoprivredi je niže 6,5 puta, u Mađarskoj 3 puta, Sloveniji 2,5 puta, a u Hrvatskoj dva puta u odnosu na RS. Zemlje u višim fazama i sa uspešnim procesom industrijalizacije imaju učešće poljoprivrede znatno ispod $10 \%$.

Brz i intenzivan pad učešća industrije i rast usluga $u$ stvaranju BDP, BDV i zaposlenosti, uz visok procenat zaposlenih u poljoprivredi, ne može se pripisati deindustrijalizaciji koja je karakteristična za razvijene zemlje. Ona se još manje može posmatrati kao proces uslovljen zrelošću industrije. U slučaju RS, pre se može govoriti o prevremenoj deindustrijalizaciji

Tabela 6 Učešće i promena zaposlenih po sektorima, 2001-2013, \%

\begin{tabular}{l|cccccccccccc}
\hline \multirow{2}{*}{$\begin{array}{r}\text { Sektori } \\
\text { proizvodni } \\
\text { princip }\end{array}$} & \multicolumn{3}{|c}{ Poljoprivreda } & \multicolumn{3}{c}{ Industrija } & \multicolumn{3}{c}{ Građevinarstvo } & \multicolumn{3}{c}{ Usluge } \\
\cline { 2 - 13 } Zemlje & 2001. & 2013. & $(+/)$ & 2001. & 2013. & $(+/)$ & 2001. & 2013. & $(+/)$ & 2001. & 2013. & $(+/-)$ \\
\hline Bugarska & 23.9 & 19.2 & -4.7 & 23.2 & 19.9 & -3.3 & 4.1 & 5.2 & +1.1 & 48.8 & 55.7 & +6.9 \\
Češka & 4.6 & 3.3 & -1.3 & 30.6 & 28.4 & -2.2 & 8.3 & 8.4 & +0.1 & 56.5 & 59.9 & +3.4 \\
Hrvatska & 16.2 & 10.7 & -5.5 & 23.6 & 20.4 & -3.2 & 6.4 & 7.1 & +0.7 & 53.8 & 61.8 & +8.0 \\
Mađarska & 11.5 & 7.1 & -4.4 & 26.3 & 20.8 & -5.5 & 6.0 & 6.4 & +0.4 & 56.2 & 65.7 & +9.5 \\
Republika Srbija & 19.5 & 21.3 & +1.8 & 34.0 & 19.6 & -14.4 & 5.4 & 4.8 & -0.6 & 41.1 & 54.3 & +13.2 \\
Slovačka & 5.9 & 3.4 & -2.5 & 28.1 & 23.6 & -4.5 & 5.9 & 7.6 & +1.7 & 60.1 & 65.4 & +5.3 \\
Slovenija & 11.1 & 8.4 & -2.7 & 29.3 & 22.7 & -6.6 & 7.3 & 6.8 & -0.5 & 52.3 & 62.1 & +9.8 \\
\hline
\end{tabular}

Napomena: Podaci su uporedivi prema klasifikaciji delatnosti iz 2010; poljoprivreda obuhvata sektor A 
kao negativnom procesu koji je doveo do devastacije industrije.

Da nije karakteristična i da je deindustrijalizacija prevremena, pokazuju empirijski podaci da se kod razvijenih zemalja maksimalno učešće industrije $u$ BDP ostvaruje kod nivoa BDP per capita između $3.000 \mathrm{i}$ 3.500 dolara. U Srbiji je taj proces počeo 1990. godine od 1.450 dolara (stalne cene iz 2000.). Da nije rezultat zrele industrije i napredne privrede, pokazuje dostignuti nivo BDP per capita od svega 1.300 dolara u 2011. godini. Jedan od razloga za to, svakako, je naglašena ekstenzivna industrijalizacija $\mathrm{u}$ periodu pre početka tranzicije. Od početka tranzicije, ne zanemarujući značaj i uticaj društveno-političkog ambijenta i faktora, devastacija je rezultat neefikasnih i loše sprovedenih tranzicionih reformi, kao i pogrešne strategije razvoja privrede $\mathrm{u}$ presudnoj fazi i na dostignutom nivou razvoja industrije. To je proizvelo duboke sistemske i strukturne neravnoteže $u$ privredi, čija je propratna pojava tercijarizacija privrede, a glavna posledica jako spor razvoj iskazan tempom rasta BDP per capita.

\section{Dostignuti nivo razvoja industrije}

Strukturne promene industrije, posebno prerađivačke, utiču i na dostignuti nivo (stepen) razvoja celokupne industrije. On se direkno odražava i na nivo njene produktivnosti i konkurentnosti, odnosno, na obim, strukturu i kvalitet izvoza.

Nivo industrijalizacije RS i posmatranih zemalja može se iskazati i uporedno analizirati putem UNIDO kvantitativnih indikatora, koji pokazuju rezultate i kretanja u prerađivačkoj industriji. Prema UNIDO klasifikaciji, RS je u 2013. godini svrstana u grupu privreda koje su u procesu industrijalizacije i podgrupu industrijskih ekonomija u razvoju (UNIDO, 2013b). Od posmatranih zemalja, u ovoj grupaciji se nalaze Bugarska i Hrvatska, dok su Češka, Slovačka, Mađarska i Slovenija u grupi industrijalizovanih ekonomija.

Kapacitet proizvodnjei izvoz prerađivačke industrije su na niskom nivou (Tabela 7). Posebno je niska apsolutna dodata vrednost proizvodnje (MVApc) i izvoza per capita (MXpc). Kapacitet proizvodnje prerađivačke industrije je 12 puta, a izvoz 15,5 puta niži od Češke, koja ima najveću dodatu vrednost proizvodnje i izvoz
Tabela 7 Kapacitet proizvodnje i izvoz prerađivačke industrije

\begin{tabular}{lcccccc}
\hline & \multicolumn{2}{c}{ MVApc } & Indeks & \multicolumn{2}{c}{ MXpc } & Indeks \\
Zemlje & 2006. & 2013. & $2013 / 06$ & 2006. & 2013. & 2013/06 \\
\hline Bugarska & 560 & 712 & 127 & 1471 & 2639 & 179 \\
Češka & 3287 & 3872 & 118 & 8572 & 14364 & 168 \\
Hrvatska & 1555 & 1363 & 88 & 2063 & 2738 & 133 \\
Mađarska & 2230 & 2403 & 108 & 6526 & 9812 & 150 \\
Republika Srbija & 391 & 320 & 82 & 533 & 931 & 175 \\
Slovačka & 2194 & 3505 & 160 & 7009 & 13389 & 191 \\
Slovenija & 3852 & 3644 & 95 & 9444 & 12784 & 135 \\
\hline
\end{tabular}

Izvor: UNIDO, 2013b; UNIDO, 2015

per capita u odnosu na posmatrane zemlje. Bugarska, koja po nivou razvoja industrije pripada istoj grupaciji kao Republika Srbija, ima kapacitet proizvodnje koji je preko 2 puta, a izvoz skoro 3 puta veći.

Ocenu dostignutog nivoa razvoja prerađivačke industrije, merenu kapacitetom proizvodnje, najbolje ilustruje činjenica da je za dostizanje nivoa dodate vrednosti proizvodnje per capita Bugarske potrebno 9,5 godina, uz pretpostavku da ona raste optimistično po stopi od $10 \%$ prosečno godišnje, a da, pri tome, dodata vrednost proizvodnje u Bugarskoj stagnira. Mada je izvoz per capita prerađivačke industrije porastao za $75 \%$ od 2006. godine, što je oko $9.5 \%$ prosečno godišnje, prethodna procena o dostizanju nivoa dodate vrednosti proizvodnje per capita pruža još pesimističniju procenu što se tiče izvoza.

Intenzitet industrijalizacije i kvalitet izvoza, odnosno, tehnološki razvoj industrije RS su na niskom nivou. Pored toga što je nizak, intenzitet industrijalizacije je u padu (Tabela 8). Doprinos prerađivačkog sektora ukupnoj novostvorenoj vrednosti (MVAsh) privrede je skroman. Nije došlo do značajnijih kvalitativnih promena strukture, povećanja tehnološke složenosti, transfera znanja i tehnološke modernizacije, tako da nije povećano učešće dodate vrednosti srednje i visoko tehnološki intenzivnih proizvoda (MHVAsh), što se odražava na obim i kvalitet izvoza.

I u pogledu kvaliteta izvoza, Republika Srbija značajno zaostaje (Tabela 9). 
Tabela 8 Intenzitet industrijalizacije

\begin{tabular}{lcccccc}
\hline & \multicolumn{3}{c}{ MVAsh, \% } & Promena & \multicolumn{3}{c}{ MHVAsh, \% } & Promena \\
Zemlje & 2006. & 2013. & 2006-13. & 2006. & 2013. & 2006-13. \\
\hline Bugarska & 14.0 & 16.0 & +2.0 & 24.2 & 25.6 & +1.4 \\
Češka & 24.2 & 28.5 & +4.3 & 44.4 & 44.6 & +0.2 \\
Hrvatska & 14.6 & 14.6 & 0.0 & 31.7 & 31.7 & 0.0 \\
Mađarska & 19.6 & 22.2 & +2.6 & 53.4 & 53.4 & 0.0 \\
R. Srbija & 17.7 & 12.0 & -5.7 & 20.7 & 20.0 & -0.7 \\
Slovačka & 20.9 & 31.5 & +10.6 & 39.8 & 43.2 & +3.4 \\
Slovenija & 20.5 & 18.9 & -1.6 & 42.6 & 45.2 & +2.6 \\
\hline
\end{tabular}

Izvor: Autor, na osnovu: UNIDO, 2013b; UNIDO, 2015

Promene $\mathrm{u}$ strukturi prerađivačke industrije utiču na nisko učešće izvoza srednje i visoko tehnološki intenzivnih proizvoda (MHXsh) u ukupnom izvozu. Učešće izvoza prerađivačke industrije u ukupnom izvozu (MXsh) smanjeno je za 1.6\%, iako je u strukturi izvoza povećano učešće srednje i visoko tehnološki intenzivnih proizvoda za 7.7\%. Globalna ekonomska kriza smanjila je izvoz proizvoda intenzivnih prirodnim resursnim i radom, što se odrazilo na kvantitet i kvalitet izvoza RS.
Tabela 9 Kvalitet izvoza

\begin{tabular}{lcccccc}
\hline & \multicolumn{2}{c}{ MXsh, \% } & Promena & \multicolumn{2}{c}{ MHXsh, \% } & Promena \\
Zemlje & 2006. & 2013. & 2006-13. & 2006. & 2013. & 2006-13. \\
\hline Bugarska & 74.9 & 78.0 & +3.1 & 27.7 & 35.9 & +8.2 \\
Češka & 92.4 & 93.2 & +0.8 & 66.1 & 67.9 & +1.8 \\
Hrvatska & 88.7 & 87.9 & -0.8 & 44.6 & 47.8 & +3.2 \\
Mađarska & 88.2 & 90.1 & +1.9 & 78.0 & 75.6 & -2.4 \\
Republika Srbija & 81.5 & 79.9 & -1.6 & 26.0 & 33.7 & +7.7 \\
Slovačka & 91.2 & 94.4 & +3.2 & 60.8 & 64.8 & +4.0 \\
Slovenija & 90.3 & 89.8 & -0.5 & 60.3 & 61.3 & +1.0 \\
\hline
\end{tabular}

Izvor: Autor, na osnovu: UNIDO, 2013b; UNIDO, 2015

Učešće industrije RS u svetskoj proizvodnji (ImWMVA) i izvozu (ImWMT) je nisko. Poređenja posmatranih zemalja pokazuju da industrijski razvijenije zemlje, kao što su Češka, Mađarska i Slovačka, imaju višestruko veće učešće prerađivačkog sektora industrije u stvaranju ukupne dodate vrednosti svetske prerađivačke industrije, kao i u svetskoj trgovini (Slika 2).

Može se zaključiti da su osnovni indikatori nivoa razvoja prerađivačke industrije RS na nezavidnom nivou (Tabela 7, 8 i 9). Tačnije, od posmatranih

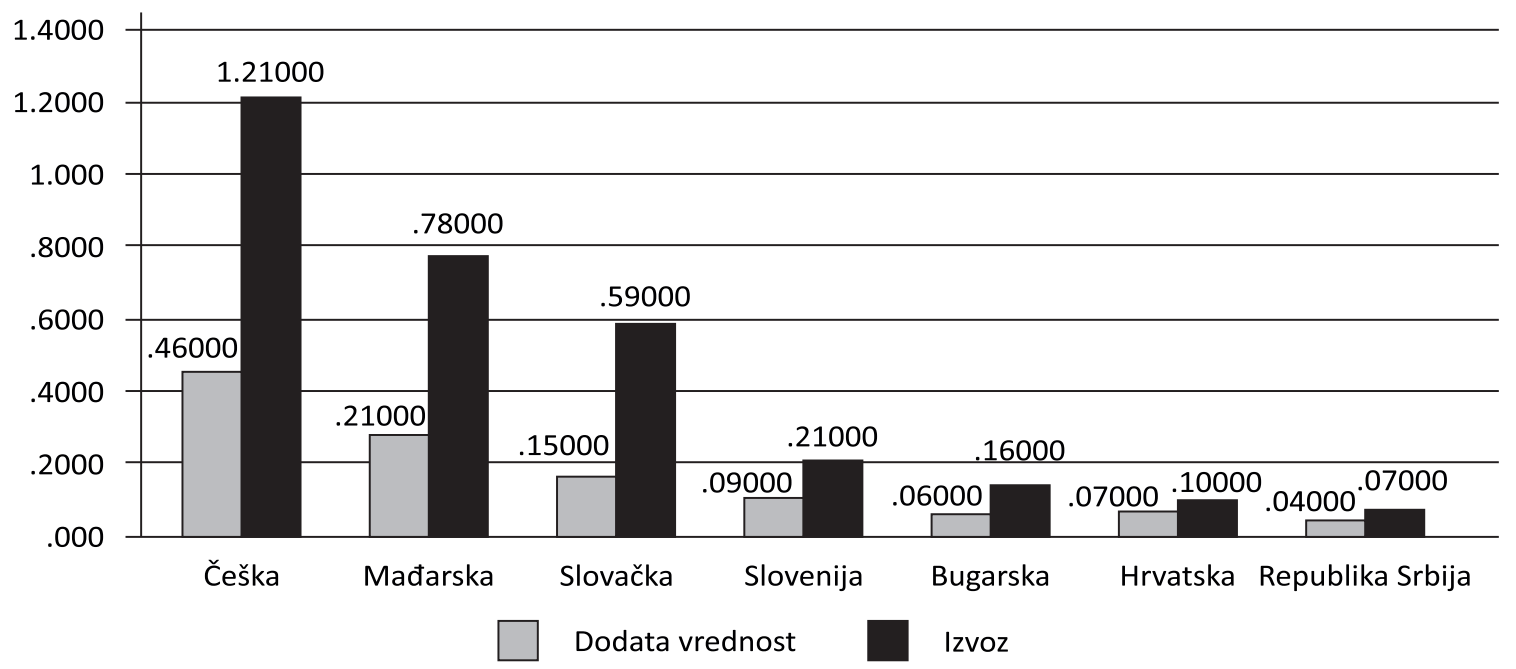

Slika 2 Učešće u svetskoj dodatoj vrednosti i izvozu u 2013. 
zemalja, Republika Srbija ima najniži nivo razvoja industrije. Smanjenje vrednosti većine indikatora, $u$ 2013. u odnosu na 2006. godinu, ukazuje na nastavak negativnih tendencija $u$ industriji, što se odražava na dalju deindustrijalizaciju privrede.

\section{DOSTIGNUTI NIVO KONKURENTNOSTI INDUSTRIJE}

Konkurentnost prerađivačke industrije, koja proizvodi najveći deo razmenljivih dobara, jedan je od osnovnih faktora održivog razvoja privrede. Produktivnost rada u prerađivačkoj industriji ključni je pokazatelj konkurentnosti. Ona je i važan pokazatelj strukturnih promena posmatranih zemalja, odnosno, sposobnosti njihovih industrija da rastu, da se razviju i da izvoze. Produktivnost se može iskazati kao dodata vrednost po zaposlenom (Tabela 10).

Od 2006. do 2013. godine, prerađivačka industrija RS imala je najviši rast produktivnosti rada mereno BDV po zaposlenom od posmatranih zemalja. Njen rast od prosečno $13.3 \%$ godišnje posledica je velikog smanjenja broja zaposlenih u prerađivačkoj industriji $(5 \%)$, a znatno manje rasta BDV (3.2\%). S obzirom na nivo nezaposlenosti, ovakav rast produktivnosti je neodrživ. On nije rezultat investicija i tehnološke modernizacije ka proizvodnim aktivnostima sa većom konkurentnošću i dodatom vrednošću, kao što je to u posmatranim zemaljama Centralne Evrope.

Da je konkurentnost prerađivačke industrije RS na niskom nivou potvrđuje 73 . pozicija od 136 rangiranih industrija u svetu, i 34 . mesto od 38 rangiranih industrija u Evropi u 2013. godini (Slika 3). Sve posmatrane zemlje imaju viši nivo konkurentnosti, što je uzrokovano njihovim boljim rezultatima u procesu razvoja industrije.

Pokazatelj kojim se može meriti i analizirati konkurentnost industrije je i UNIDO Competitive Industrial Performance Index - CIP indeks, koji se kreće $\mathrm{u}$ intervalu od 0 do 1 . Pored toga, on pokazuje produktivnost i strukturne promene. Radi se o kompozitnom indeksu koji meri sposobnost industrije da proizvodi i izvozi konkurentne proizvode. Može se izračunati putem više metoda, dok se po linearnom agregatnom metodu izračunava na sledeći način:

$C I P_{j t}=\sum_{i=1}^{q} w_{i} I_{i j t}$

$\mathrm{U}(1), C I P_{j t}$ je indeks zemlje $j \mathrm{u}$ godini $t$. Ponder $w_{i}$ se odnosi na $i$ indikatore, a zbir svih pondera je 1. Ponderi $w_{i}$ uzimaju vrednosti $1 / 6$ za indikatore MVApc, MXpc, ImWMVA i ImWMT, a 1/12 za indikatore MHVAsh, MVAsh, MHXsh i MXsh. $I_{i j t}$ je vrednost indeksa $i$ za zemlju $j \mathrm{u}$ godini $t$. $U$ linearnom proračunu, indeks

Tabela 10 Kretanje produktivnosti prerađivačke industrije, 2006-2013.

\begin{tabular}{|c|c|c|c|c|c|c|}
\hline \multirow[b]{2}{*}{ Zemlje } & \multicolumn{3}{|c|}{ BDV po zaposlenom, u evrima } & \multirow{2}{*}{$\begin{array}{l}\text { Prosečna } \\
\text { stopa rasta } \\
\text { BDV po } \\
\text { zaposlenom }\end{array}$} & \multirow{2}{*}{$\begin{array}{c}\text { Prosečna } \\
\text { stopa rasta } \\
\text { zaposlenih }\end{array}$} & \multirow{2}{*}{$\begin{array}{c}\text { Prosečna } \\
\text { stopa rasta } \\
\text { BDV }\end{array}$} \\
\hline & 2006. & 2013. & Promena & & & \\
\hline Bugarska & n.p.* & n.p. & n.p. & n.p. & -1.7 & n.p. \\
\hline Češka & 21573 & 26627 & 5054 & +3.3 & -0.3 & +5.1 \\
\hline Hrvatska & 17137 & 19634 & 2497 & +2.0 & -1.8 & -1.5 \\
\hline Mađarska & 20299 & 25095 & 4796 & +3.4 & -2.0 & +0.1 \\
\hline Republika Srbija & 8251 & 19197 & 10946 & +13.3 & -5.0 & +3.2 \\
\hline Slovačka & 18945 & 28943 & 9998 & +7.0 & -0.9 & +5.9 \\
\hline Slovenija & 28308 & 37086 & 8778 & +4.1 & -2.8 & +0.8 \\
\hline
\end{tabular}

* nema podataka 


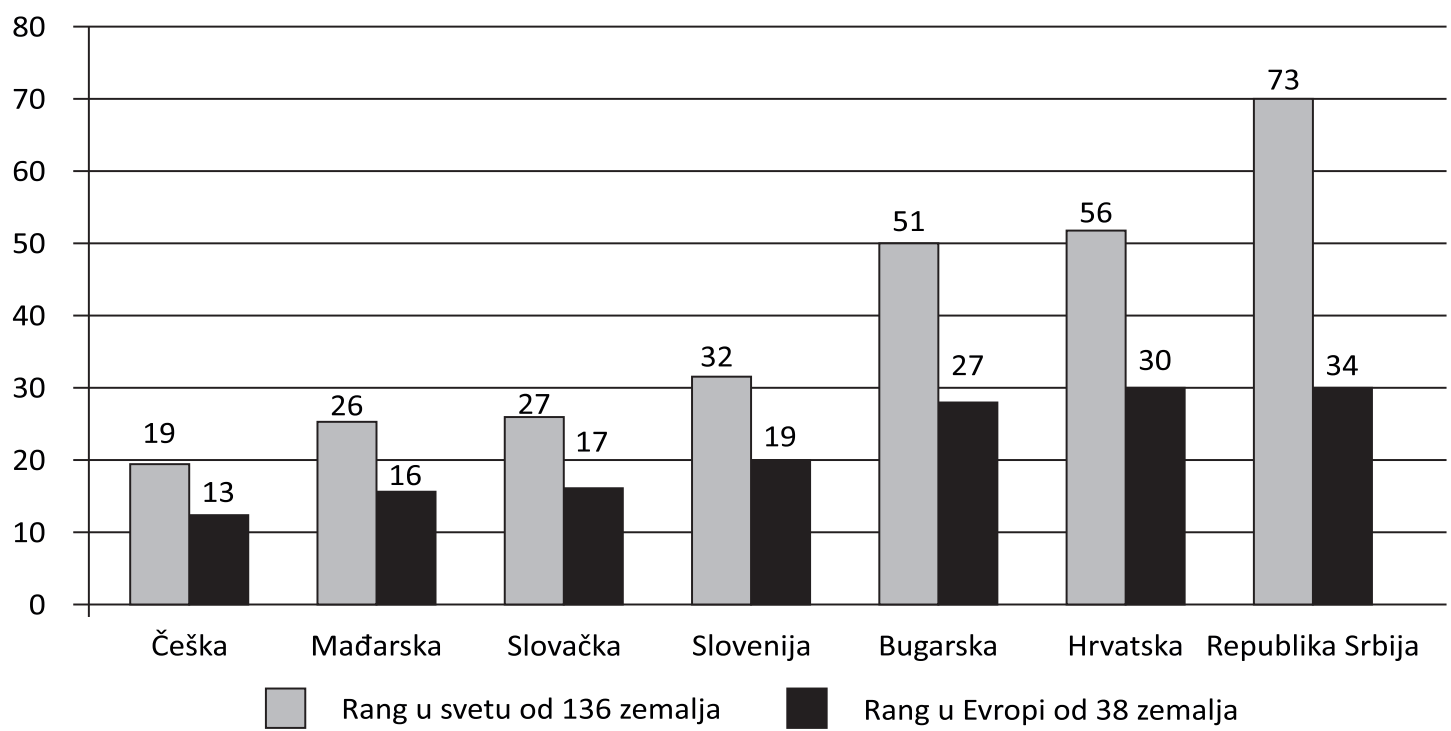

Slika 3 Rang konkurentnosti prerađivačkih industrija posmatranih zemalja u 2013.

Izvor: Autor, na osnovu: UNIDO, 2013b; UNIDO, 2015.

$I_{i j t}$ se izračunava kao $\left(X_{i j t}-\min X_{i j t}\right) /\left(\max X_{i j t}-\min X_{i j j}\right)$. $X_{i j t}$ je vrednost indikatora $i$ za zemlju $j$ u godini $t$, pri čemu su min (max) vrednosti analiziranog indikatora u uzorku posmatranih zemalja (UNIDO, 2013b).

U odnosu na grupu posmatranih zemalja, prerađivačka industrija RS ima vrednost CIP indeksa 0,031 u 2013. godini (Slika 4). Sve analizirane zemlje imaju višestruko veću vrednost CIP indeksa, što znači da imaju veći nivo produktivnosti i intenzitet strukturnih promena. Ovo potvrđuje da je nivo razvoja i konkurentnost industrije RS i posmatranih zemalja $\mathrm{u}$ korelaciji sa intenzitetom industrijalizacije.

Potvrdu veze predstavljaju i vrednosti Pearson-ovog koeficijenta korelacije sedam posmatranih zemalja između novostvorene vrednosi, CIP indeksa, izvoza i intenziteta industrijalizacije u 2013. godini (Tabela 11). Posebno su izražene kod veličine učešća dodate vrednosti srednje i visoko tehnološki intenzivnih proizvoda (MHVAsh).

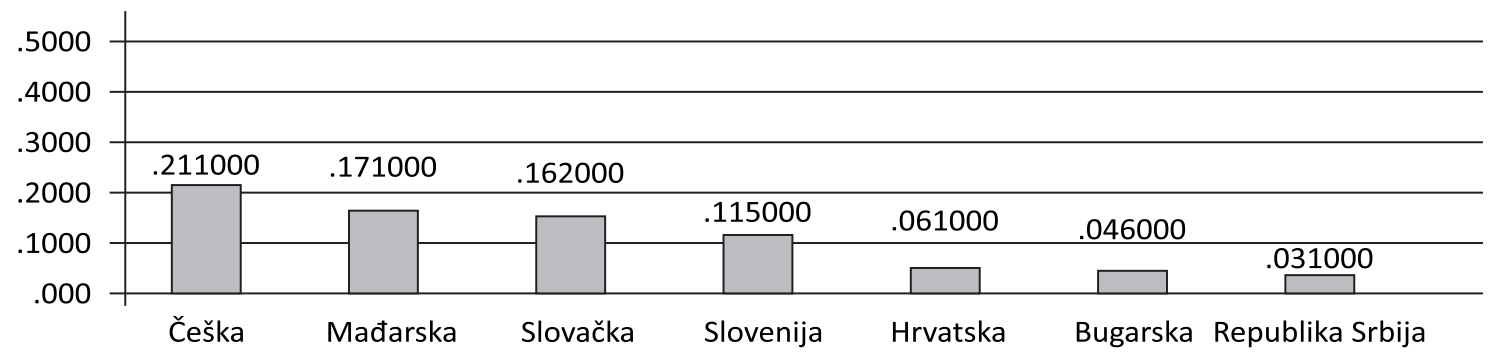

Slika 4 Vrednost CIP indeksa posmatranih zemalja za 2013. 
Tabela 11 Pearson-ov koeficijent korelacije sedam posmatranih zemalja za 2013.

\begin{tabular}{lcccccc}
\hline MVApci MVAsh & $\begin{array}{l}\text { MVApci } \\
\text { MHVAsh }\end{array}$ & CIP i MVAsh & CIPi MHVAsh & MVApciCIP & MXpci MVAsh & MXpci MHVAsh \\
\hline 0.8288 & 0.8327 & 0.7009 & $0.8798^{*}$ & $0.8794^{*}$ & 0.8716 & 0.8543 \\
\hline
\end{tabular}

Korelacija je značajna na nivou 0.05 (2-tailed); *korelacija je značajna na nivou 0.01 (2-tailed)

Izvor: Autor

Kod posmatranih zemalja, to potvrđuje da kvalitativne promene strukture, transfer znanja, tehnološka složenost i modernizacija, odnosno, intenzitet pomeranja od tradicionalnih ka proizvodima veće produktivnosti, konkurentnosti i dodate vrednosti, utiču na ostvareni intenzitet industrijalizacije. Za RS, niska dodata vrednosti per capita i niska vrednost kompozitnog CIP indeksa znači visoku korelaciju između niskog nivoa razvoja, niske konkurentnosti i niskog intenziteta strukturnih promena prema propulzivnim aktivnostima.
Nužnost strukturnih promena u glavnim proizvodnim i izvoznim aktivnostima

Tri od davdeset četiri oblasti prerađivačke industrije RS stvaraju 50\% dodate vrednosti. Dominiraju proizvodnja hrane, pića i duvana $(33 \%)$, proizvodnja metalnih proizvoda (9\%) i koksa i derivata nafte $(8 \%)$. Struktura proizvodnje prerađivačke industije pokazuje da je ona bazirana na resursno i radno intenzivnim proizvodima i proizvodima niske i srednje niske tehnološke intenzivnosti (Tabela 12). Pored toga što

Tabela 12 Učešće tri glavne proizvodne aktivnosti u BDV u 2013.

\begin{tabular}{|c|c|c|c|}
\hline Zemlje & Oblasti - ISIC revizija 4. & Ukupno & Tehnološka klasifikacija (OECD) \\
\hline Bugarska & $\begin{array}{l}\text { Hrana, piće i duvan (18\%) } \\
\text { Mašine i oprema (11\%) } \\
\text { Tekstil, odeća, koža (10\%) }\end{array}$ & $39 \%$ & $\begin{array}{l}\text { Niska (28\%) i srednje-visoka (11\%) } \\
\text { tehnološka intenzivnost proizvoda }\end{array}$ \\
\hline Češka & $\begin{array}{l}\text { Motorna vozila (18\%) } \\
\text { Metalni proizvodi }(11 \%) \\
\text { Mašine i oprema }(10 \%\end{array}$ & $39 \%$ & $\begin{array}{l}\text { Srednje-visoka (28\%) i srednje-niska } \\
(11 \%) \text { tehnološka intenzivnost } \\
\text { proizvoda }\end{array}$ \\
\hline Hrvatska & n.p. & n.p. & n.p. \\
\hline Mađarska & $\begin{array}{l}\text { Motorna vozila (17\%) } \\
\text { Mašine i oprema (16\%) } \\
\text { Hrana, piće i duvan (11\%) }\end{array}$ & $44 \%$ & $\begin{array}{l}\text { Srednje-visoka ( } 33 \%) \text { i niska (11\%) } \\
\text { tehnološka intenzivnost proizvoda }\end{array}$ \\
\hline Republika Srbija & $\begin{array}{l}\text { Hrana, piće i duvan }(33 \%) \\
\text { Metalni proizvodi }(9 \%) \\
\text { Koks i derivati nafte }(8 \%)\end{array}$ & $50 \%$ & $\begin{array}{l}\text { Niska (33\%) i srednje-niska ( } 17 \% \text { ) } \\
\text { tehnološka intenzivnost proizvoda }\end{array}$ \\
\hline Slovačka & $\begin{array}{l}\text { Motorna vozila }(17 \%) \\
\text { Mašine i oprema }(12 \%) \\
\text { Električna oprema }(9 \%)\end{array}$ & $38 \%$ & $\begin{array}{l}\text { Srednje-visoka (38\%) tehnološka } \\
\text { intenzivnost proizvoda }\end{array}$ \\
\hline Slovenija & $\begin{array}{l}\text { Hemijski proizvodi (17\%) } \\
\text { Metalni proizvodi (14\%) } \\
\text { Mašine i oprema (11\%) }\end{array}$ & $42 \%$ & $\begin{array}{l}\text { Srednje-visoka (28\%) i srednje-niska } \\
(14 \%) \text { tehnološka intenzivnost } \\
\text { proizvoda }\end{array}$ \\
\hline
\end{tabular}


su niskog stepena finalizacije, ti proizvodi imaju nizak nivo produktivnosti i dodate vrednosti. To potvrđuje ekonomsku zakonitost da je na nižem nivou produktivnosti rada proizvodna ponuda ograničena upravo na ovakve poizvode.

Podaci o raspodeli BDV prema tri dominirajuće proizvodne oblasti ilustruju razlike $u$ strukturi proizvodnje prerađivačkih industrija RS i posmatranih zemalja. U proizvodnji posmatranih zemalja dominiraju oblasti proizvodnje motornih vozila, mašina i opreme, hemikalija i hemijskih proizvoda, elektične opreme i metalnih proizvoda. To su proizvodi srednje-visoke i srednje-niske intenzivnosti i intenziteta radnih veština $i$ znanja. Radi se o propulzivnim oblastima proizvodnje koja je važna za tehnološki napredak i zaposlenost. Ove oblasti imaju veći uticaj na rast produktivnosti i rast konkurentnosti, i, takođe, stvaraju veću dodatu vrednost, što utiče i na njihov izvozni potencijal.

U strukturi izvoza RS, prema SMTK, Rev. 4, najveće učešće imaju proizvodi Sektora 7 (mašine i transportna sredstva 31\%), sektora 6 (proizvodi svrstani po materijalu 20\%) i nultog i prvog sektora (hrana, piće i duvan 17\%) (Tabela 13). Od 2012. godine rastuće učešće ima sektor 7 , a u okviru njega posebno proizvodnja automobila. Ovakva struktura ne prati učešće $u$ strukturi stvaranja $B D V$, što je posedica toga da izvoz prati ciklična kretanja na svetskom tržištu, i što je mnogo uticajnije, da se najveći delo tehnološki kompleksnih komponenata za finalizaciju proizvodnje automobila uvozi. Potencijal povećanja BDV je u proizvodnji komponenata koje se uvoze. To se multiplikatorski prenosi i na proizvodnju tehnološki intezivne mašinogradnje i elektronske opreme, što je slučaj u posmatranim zemljama.

Tri vodeća sektora u izvozu, prema SMTK, Rev. 4, ukazuju na nepovoljnu strukturu i obim izvoza RS u poređenju, posebno sa Češkom, Slovačkom i Mađarskom. U strukturi izvoza ovih zemalja dominira proizvodnja drumskih vozila i automobila, specijalnih i mašina za obradu podataka, električnih uređaja, aparata i opreme, čija proizvodnja zahteva primenu visoke tehnologije i visoko kvalifikovan rad, što nije slučaj sa RS. Ovakvom proizvodnom i izvoznom strukturom teško se može konkurisati posmatranim
Tabela 13 Izvoz tri glavne proizvodne aktivnosti učešće i obim 2013.

\begin{tabular}{|c|c|c|c|}
\hline Zemlje & $\begin{array}{l}\text { SMTK, Rev. } \\
4 \text { Sektori }\end{array}$ & Učešće, \% & $\begin{array}{c}\text { Vrednost, } \\
\text { milioni dolara }\end{array}$ \\
\hline \multirow{3}{*}{ Bugarska } & Sektor 6 & $22 \%$ & 6494 \\
\hline & Sektor 7 & $18 \%$ & 5197 \\
\hline & Sektor 3 & $15 \%$ & 4346 \\
\hline \multirow{3}{*}{ Češka } & Sektor 7 & $54 \%$ & 87095 \\
\hline & Sektor 6 & $17 \%$ & 28058 \\
\hline & Sektor 8 & $12 \%$ & 18723 \\
\hline \multirow{3}{*}{ Hrvatska } & Sektor 7 & $24 \%$ & 2813 \\
\hline & Sektor 6 & $16 \%$ & 1879 \\
\hline & Sektor 3 & $15 \%$ & 1735 \\
\hline \multirow{3}{*}{ Mađarska } & Sektor 7 & $52 \%$ & 56353 \\
\hline & Sektor 6 & $12 \%$ & 11460 \\
\hline & Sektor 5 & $12 \%$ & 11380 \\
\hline \multirow{3}{*}{ Republika Srbija } & Sektor 7 & $31 \%$ & 2417 \\
\hline & Sektor 6 & $20 \%$ & 2913 \\
\hline & Sektor $0+1$ & $17 \%$ & 4541 \\
\hline \multirow{3}{*}{ Slovačka } & Sektor 7 & $57 \%$ & 48844 \\
\hline & Sektor 6 & $17 \%$ & 14595 \\
\hline & Sektor 8 & $9 \%$ & 7371 \\
\hline \multirow{3}{*}{ Slovenija } & Sektor 7 & $36 \%$ & 10201 \\
\hline & Sektor 6 & $21 \%$ & 6000 \\
\hline & Sektor 5 & $18 \%$ & 5275 \\
\hline
\end{tabular}

Napomena: Sektor 0 - Hrana i žive životinje; Sektor 1 - Piće i duvan; Sektor 3 - Mineralna goriva i maziva; Sektor 5 - Hemijski proizvodi; Sektor 6 - Proizvodi svrstani po materijalu; Sektor 7 - Mašine i transportni uređaji; Sektor 8 - Razni gotovi proizvodi

Izvor: Autor, na osnovu: UNIDO, 2015; Eurostat, 2015

zemljama. Stoga, buduću ponovnu industijalizaciju potrebno je da prati, pored povećanja produktivnosti rada u postojećoj proizvodnji, promena proizvodne orijentacije $\mathrm{u}$ pravcu proizvoda sa višim nivoom dodate vrednosti. 


\section{ZAKLJUČAK}

Veći broj teorijskih analiza, kao i ekonomska realnost, pokazuju da je za uspešan ekonomski razvoj bitna industrijalizacija, koja je pokretač kontinuiranih srukturnih promena, što ima poseban značaj za zemlje u razvoju. Ostvareni rezultati razvoja industrije RS do početka procesa tranzicije su značajni. Međutim, umesto da je ovaj proces doveo do kvalitativnog skoka u razvoju, on je označio početak duboke krize razvoja industrije, koja i danas traje. Nizak tempo rasta pokazuje da je kriza u industriji strukturne prirode, $\mathrm{i}$ da je $\mathrm{u}$ takvim uslovima kretanje prema propulzivnoj proizvodnoj strukturi otežano.

Strukturne promene privrede i intenzivna deindustrijalizacija nisu posledica zrelosti industrije i njene razvijene strukture. Nagla i prevremena deindustrijalizacija, kao i sprovedene tranzicione reforme i primenjena strategija razvoja privrede, doveli su do devastacije industrije. Potvrdu prve hipoteze, da je u RS neophodno sprovesti ponovnu industrijalizaciju i strukturne promene industrije, predstavlja dostignuti nivo ekonomskog razvoja meren BDP per capita. On je 2013. godine iznosio 90\% od onog koji je ostvaren 1990. godine.

Dostignuti nivo razvoja industrije RS je nizak, posebno u odnosu na Češku, Slovačku, Mađarsku i Sloveniju. Prema nivou razvoja industrije, RS se svrstava $u$ najmanje razvijene evropske industrije, a time i privrede. Kapacitet proizvodnje, nivo tehnološog razvoja, intenzitet industrijalizacije $\mathrm{i}$ kvalitet izvoza imaju tendenciju pada, što uzrokuje dalju deindustrijalizaciju i utiče na nizak nivo produktivnosti rada i konkurentnost industrije.

Druga hipoteza, da je nivo razvijenosti i konkurentnosti industrije Republike Srbije i posmatranih zemalja u korelaciji sa intenzitetom industrijalizacije, $u$ radu je potvrđena preko nivoa produktivnosti rada i nivoa konkurentnosti. Visok rast produktivnosti rada, iskazan BDV po zaposlenom je neodrživ, zato što nije rezultat pomeranja ka proizvodnim aktivnostima sa većom dodatom vrednošću, već posledica velikog smanjenja broja zaposlenih. Niska dodata vrednost per capita i niska vrednost CIP indeksa prerađivačke industrije znače visoku pozitivnu korelaciju između niskog nivoa razvoja i niske konkurentnosti, s jedne, i niskog intenziteta strukturnih promena, s druge strane.

Osnovni doprinos ovoga rada jeste u kritičkom preispitivanju deindustrijalizacije, strukturnih promena, nivoa razvoja i konkurentnosti industrije, kao i ukazivanje na važnost i značaj ponovne industrijalizacije RS. Primarni cilj ponovne industrijalizacije je rast konkurentnosti industrije, čime bi se obezbedio rast proizvodnje, zaposlenosti, izvoza, i što je najvažnije, rast ukupnog životnog standarda građana. S obzirom na prikazane karakteristike i probleme industrije, izazovi ponovne industrijalizacije su brojni i zahtevaju dosta napora i ulaganja.

Osnovno ograničenje $u$ ovom radu jeste raspoloživost adekvatnih i uporedivih podataka u dovoljno dugom vremenskom periodu, odnosno, podataka na nižim klasifikacionim nivoima industrije, kao što je nivo grane ili grupe. Ovo isključuje i mogućnost primene drugih kompleksnih pokazatelja, kojim se meri intenzitet strukturnih promena $\mathrm{u}$ industriji.

Struktura proizvodnje i izvoza prerađivačke industrije na nivou oblasti, pokazuje da je čine proizvodi koji stvaraju malu dodatu vrednost. To potvrđuje ekonomsku zakonitost da je na nižem nivou produktivnosti rada ponuda ograničena upravo na ovakve poizvode. Stoga će pažnja u daljim istraživanjima biti usmerena na povezanost komparativnih prednosti sa promenom proizvodne strukture, kao i na uticaj izvoza i investicija na promenu proizvodne strukture RS.

U praktičnom smislu, rad može predstavljati predložak kreatorima i nosiocima ekonomske i industrijske politike $\mathrm{u}$ pogledu pokretanja procesa ponovne industrijalizacije i stukturnih promena. $U$ radu se ukazuje na to da ekonomski rast i održivi razvoj i kanalisanje procesa promena industrijske strukture, posebno $\mathrm{u}$ uslovima krize $\mathrm{u}$ kojoj se nalazi industrija RS, nisu mogući bez celovite i konzistentne industrijske politike. Uspešnost rešavanja navedenih izazova, opredeljena je spremnošću države da, konceptom razvojne uloge, kreira novu strategiju ekonomskog razvoja i industrijsku politiku, koju ne treba shvatiti kao klasičnu državnu intervenciju. 
Važna poruka rada, koja bi mogla biti od koristi i za kreatore industrijske politike, jeste da ona treba da bude aktivna i sofisticirana, kako bi uticala na kontinuirane strukturne promene, transfer i razvoj visokih tehnologija, razvoj kako malih i srednjih, tako i velikih preduzeća, kao i na sprovođenje strategije izvoznog usmerenja, što su ključne pretpostavke održivosti ekonomskog razvoja i rešavanja nezaposlenosti, kao gorućeg problema društva. Ovakav koncept industrijske politike bi uticao na stvaranje propulzivnije strukture i veće dodate vrednosti industrije, što je neophodno za efikasniji nastup na svetskom tržištu.

Neophodno je da kreatori industrijske politike, zbog stanja devastiranosti industrije, iniciraju kontinuirane strukturne promene. Uslov kontinuiranih strukturnih promena jeste stvaranje zdravog poslovnog ambijenta, makroekonomska stabilnost, raspoloživost kapitala, ulaganje $u$ obrazovanje potrebnih kadrova, ulaganje $\mathrm{u}$ istraživanje i razvoj, razvoj fizičke i nematerijalne infrastrukture i afirmacija industrijskih preduzeća na stranim tržištima.

\section{REFERENCE}

Aiginger, K. (2014). Industrial Policy for a sustainable growth path. Policy Paper no 13, WWWforEurope.

Doyle, E. (1997). Structural change in Ireland: The contribution of sectoral employment distribution to labour productivity convergence between Ireland and the EU: 1970-1990. Journal of Economic Studies, 24(1/2), 59-71.

European Bank for Reconstruction and Development (EBRD). (29. January 2015). Statistical databases. Retrieved 29. January 2015, from http://www.ebrd.com/what-we-do/economicresearch-and-data/data.html.

Eurostat. (29. January 2015). Statistical databases. Retrieved 29. January 2015, from http://ec.europa.eu/eurostat/data/ database.

Fagerberg, J. (2000) Technological progress, structural change and productivity growth: a comparative study. Structural Change and Economic Dynamics, 11(4), 393-418.

Jakopin, E. (2012). Post-crisis reallocation of growth factors. Economic Horizons, 14(2), 79-90. doi: 10.5937/ekonhor1202077J

Kollmeyer, C. (2009). Explaining Deindustrialization: How
Affluence, Productivity Growth, and Globalization Diminish Manufacturing Employment. American Journal of Sociology, 114(6), 1644-1674.

Kucera, D., \& Milberg, W. (2003). Deindustrialization and changes in manufacturing trade: Factor content calculations for 1978-1995. Review of World Economics, 139(4), 601-624.

Lin, J., \& Chang, H. J. (2009). Should Industrial Policy in Developing Countries Conform to Comparative Advantage or Defy it? Development Policy Review, 27(5), 483-502. doi. org/10.1111/j.1467-7679.2009.00456.x

Lin, Y. J. (2012). New Structural Economics: A Framework for Rethinking Development and Policy. Washington: The World Bank. doi: 10.1596/978-0-8213-8955-3

Mickiewicz, T., \& Zalewska, A. (2005). De-industrialisation and the post-communist transition: Rowthorn and Wells' model revisited. Economics Working Papers 59, Centre for the Study of Economic and Social Change in Europe, SSEES, UCL: London, UK.

Naude, W., Szirmai, A., \& Lavopa, A. (2013). Industrialization lessons from BRICS: A comparative analysis. IZA Discussion Paper No.7543, University of Maastricht, The Netherlands.

Pack, H., \& Westphal, L. E. (1986). Industrial strategy and technological change: Theory versus reality. Journal of development economics, 22(1), 87-128.

Palma, J. G. (2008). Deindustrialisation, Premature Deindustrialisation, and the Dutch Disease'. In S. N. Durlauf, \& L. E. Blume, (Eds.), The New Palgrave: A Dictionary of Economics, 2nd edition. Basingstoke: Palgrave Macmillian, pp. 7-23. doi:10.1057/9780230226203.0369

Republički zavod za statistiku. (2015). Statistička baza podataka

Rodrik, D. (2007). Industrial development: Some stylized facts and policy directions. Industrial Development for the 21st century: Sustainable Development Perspectives, New York, NY: United Nations. 7-28.

Rodrik, D. (2008). Normalizing industrial policy. Commission on growth and development working paper No. 3. Washington: World Bank. Retrieved June 1, 2009, from http://documents. worldbank.org/curated/en/2008/01/13163290/normalizingindustrial-policy

Rodrik, D. (2009). Industrial policy: don't ask why, ask how. Middle East Development Journal, 1(1), 1-29.

Rowthorn, R., \& Coutts, K. (2004). De-industrialisation and the balance of payments in advanced economies. Cambridge Journal of Economics, 28(5), 767-790. doi: 10.1093/cje/beh034 
Syrquin, M. (2007). Structural Change and Development. In A. K. Dutt, \& J. Ros, (Eds.), International Handbook of Development Economics, Vol. 1, UK: Edward Elgar Publishing.

Szirmai, A. (2012). Industrialisation as an engine of growth in developing countries, 1950-2005. Structural Change and Economic Dynamics, 23(4), 406-420.

Szirmai, A., Naude, W., \& Alcorta, L. (2013). Introduction and Overview: The Past, Present and Future of Industrialization. In A. Szirmai, W. Naude, \& L. Alcorta, (Eds.), Pathways to Industrialization in the Twenty-First Century-New Challenges and Emerging Paradigms. Oxford: Oxford University Press. doi:10.1093/acprof:oso/9780199667857.003.0001

Tregenna, F. (2009). Characterising Deindustrialisation: An Analysis of Changes in Manufacturing Employment and GDP Internationally. Cambridge Journal of Economics, 33(3), $433-466$.

Tregenna, F. (2011). Manufacturing productivity, deindustrialization, and reindustrialization. WIDER
Working Paper 57, United Nations University, World Institute for Development Economics Research.

UNIDO. (2013a). Industrial Development Report 2013, Sustaining Employment Growth: The Role of Manufacturing and Structural Change. Vienna.

UNIDO. (2013b). The Industrial Competitiveness of Nations Looking back, forging ahead. Vienna.

United Nations Economic Commission for Europe (UNECE). 1. February 2015, Statistical databases. Retrieved 1. February 2015, from http://www.unece.org/stats/econ.html

United Nations Industrial Development Organization (UNIDO). (29. January 2015). Statistical databases. Retrieved 29. January 2015, from http://www.unido.org/en/resources/ statistics /statistical-databases.html

Wade, R. H. (2012). Return of industrial policy? International Review of Applied Economics, 26(2), 223-239. doi:10.1080/02692 171.2011.640312

Primljeno 26. februara 2015, nakon revizije, prihvaćeno za publikovanje 6. aprila 2015.

Elektronska verzija objavljena 21. aprila 2015.

Vladimir Mićić je docent na Ekonomskom fakultetu Univerziteta u Kragujevcu, gde je doktorirao u naučnoj oblasti Opšta ekonomija i privredni razvoj. Izvodi nastavu na nastavnim predmetima Ekonomika industrije, Privredni razvoj i Ekonomika rasta i razvoja. Oblasti njegovog istraživačkog interesovanja su relevantna pitanja industrijske politike, konkurentnosti i privrednog razvoja. 


\title{
REINDUSTRIALIZATION AND STRUCTURAL CHANGE IN FUNCTION OF THE ECONOMIC DEVELOPMENT OF THE REPUBLIC OF SERBIA
}

\author{
Vladimir Micic \\ Faculty of Economics, University of Kragujevac, Kragujevac, The Republic of Serbia
}

This paper examines industrialization and structural change induced thereof, which are the main drivers and bearers of economic development. The author observes that the industry of the Republic of Serbia is devastated due to sudden and premature tertiarization as well as inadequate reforms. The current structures of both the economy and the industry do not have a sufficient capacity to ensure sustainable economic development; hence, the aim of the research presented in this paper is to emphasize the importance of reindustrialization and the implementation of structural changes in the Republic of Serbia. The papeRStarts from the premise that industry is the main driver and the bearer of economic growth and development. Therefore, it is necessary for the Republic of Serbia to turn to reindustrialization and implement structural changes in this sector given the fact that the levels of the development and competitiveness of the industry are correlated to the intensity of industrialization. The research findings indicate that developed industrial countries are characterized by more effective structural changes and more propulsive production that creates higher value-added products. This reflects not only at the level of the industrial development but also at the level of the competitiveness, volume and quality of exports.

Keywords: industrialization, structural change, the level of industry development and competitiveness, economic development

JEL Classification: L16, N1, O14, O25, O47 